\title{
Biochemical, Structural and Pathophysiological Aspects of Prorenin and (Pro)renin Receptor
}

\author{
A.H.M. Nurun $\mathrm{Nabi}^{1}$ and Fumiaki Suzuki ${ }^{2}$ \\ ${ }^{1}$ Department of Biochemistry and Molecular Biology, \\ University of Dhaka, Dhaka, Bangladesh; \\ ${ }^{2}$ Laboratory of Animal Biochemistry, Faculty of Applied Biological Sciences, Gifu \\ University, 1-1 Yanagido, Gifu, \\ Japan
}

\section{Introduction}

Our knowledge of understanding the complex role of renin angiotensin system (RAS) or RA system in human physiology has been widened for more than 100 years and it is rapidly increasing day-by-day. Over the last two decades discoveries of angiotensin converting enzyme 2 (ACE 2), putative receptor for angiotensin (Allen et al., 2006; Aronsson et al. 1988; Bickerton \& Buckley, 1961; Cooper et al., 1996; Deschepper et al., 1986; Dzau et al., 1986; Epstein et al., 1970), and (pro)renin receptor have laid the foundation of many new hypotheses in the context of their biochemical actions, physiological effects and activation of second messenger pathways. Thus, scientists have started to reconsider the complex biochemistry and physiology of RAS. The primary and main role of this system is to regulate homeostasis of body fluid that ultimately maintains the blood pressure (Kobori et al., 2006; Oparil \& Haber, 1974a; Oparil \& Haber; 1974b). This system catalyzes a liver product, angiotensinogen, to generate a small decapeptide, angiotensin-I (Ang-I). Angiotensin converting enzyme (ACE), thus, converts Ang-I into octapeptide, angiotensin-II (Ang-II). Ang-II acts directly within the central nervous system to increase blood pressure (Bickerton \& Buckley, 1961). Injection of purified Ang-II peptide around the hypothalamus in rat brain stimulated thriving drinking response (Epstein et al., 1970). The physiological actions of the most potent hormone peptide are mediated via G-protein coupled angiotensin II type 1 (AT1) and angiotensin II type 2 (AT2) receptors. Ang-II facilitates vasoconstriction, cell proliferation, cell hypertrophy, anti-natriuresis, fibrosis, atherosclerosis using AT1 (Ito et al., 1995) while, via AT2 receptor, the peptide elicits vasodilation, anti-proliferation, antihypertrophy, anti-fibrosis, anti-thrombosis, anti-angiogenesis (Siragy \& Carey, 1997; Goto et al., 1997; Gross et al., 2000). The classical renin angiotensin system with the generation of different peptides and their physiological effects has been presented in Figure 1.

The systemic or classical renin angiotensin system has usually been viewed as the bloodborne cascade whose ultimate product Ang-II plays the pivotal endocrine role. Plasma renin activity is the most accepted clinical marker of circulating RAS. However, circulating RAS remained unsuccessful to describe the autocrine and paracrine functions mediated by RAS within specific tissue sites particularly in heart, kidney, brain and vasculature. Transgenic 


\section{Classical Renin-Angiotensin System}

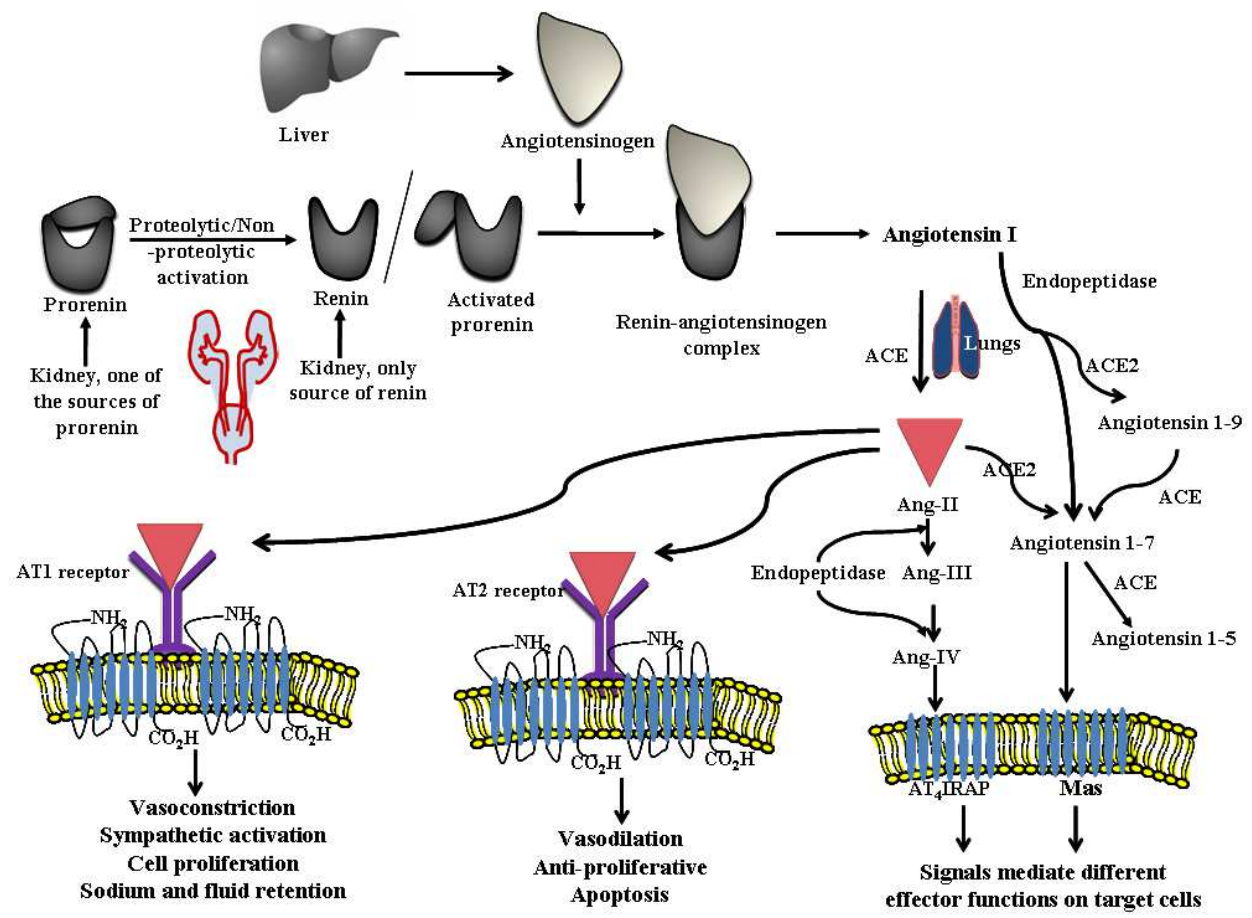

Fig. 1. Schematic diagram of the classical renin-angiotensin (RA) system shows angiotensinII dependent pathway mediated different physiological effects via angiotensin type 1 (AT1) and type 2 (AT2) receptors. Renin, secreted from kidney, regulates the rate limiting step of this pathway by converting its liver originated macromolecule substrate angiotensinogen into a short peptide, angiotensin-I (Ang-I). Angiotensin-I, thus, is converted into angiotensin-II (Ang-II) by angiotensin converting enzyme. Other peptide products via stimulation of enzymes and receptor subtypes on target cells can also mediate physiological functions.

animals facilitate to demonstrate the existence of tissue RAS parallel to and independent of systemic RAS. Thus, local RA system has been ensured in intracellular compartments (de Mello, 1995; van Kesteren et al., 1997; Admiraal et al., 1999), interstitial fluids (de Lannoy et al., 1997, 1998), cardiac cells including fibroblasts, endothelial cells, myocytes, macrophages (de Lannoy et al., 1998; Hokimoto et al., 1996; Sun et al., 1994) as well as on the cell membrane (Danser et al., 1992; Neri Serneri et al., 1996). All the circulating components of renin angiotensin system i.e., renin, angiotensinogen, ACE, and Ang I and II though not produced but have been identified in cardiac tissue (Campbell et al., 1993; Danser et al., 1994). As a consequence, presence of local RAS in the heart could contribute to the pathogenesis of congestive heart failure, cardiac hypertrophy and remodeling, and reperfusion arrhythmias (Yusuf et al., 1991: Ruzicka et al., 1994; Schieffer et al., 1994; Van 
Gilst et al., 1984). Direct action of Ang II within the central nervous system causes increased blood pressure. Also, presence of renin and endogenous production of angiotensin have established the existence of local RAS in the central nervous system (Bickerton and Buckley et al., 1961; Fischer-Ferraro et al., 1971; Ganten et al., 1971).

\subsection{The main players associated with renin angiotensin system}

The RA system is initiated by its rate-limiting enzyme renin (37 kDa with 340 amino acid residues) which catalyzes its only known substrate angiotensinogen. Renin is only secreted from kidney as preprorenin and levels of renin in the plasma of nephrectomized animals is not detectable. Professor Robert A. Tigerstedt and his student Per G. Bergman for the first time reported a "pressor" substance in the kidney extract more than 100 years ago, which caused increase in blood pressure in experimental animals and later, coined that substance as renin (Tigerstedt \& Bergman, 1898). Renin, also known as aspartyl proteinase having an optimum $\mathrm{pH}$ of 5.5 to 7.5 instead of 2.0 to 3.4, has no known physiological effect other than the proteolysis of angiotensinogen (Murakami \& Inagami, 1975; Inagami \& Murakami, 1977; Matoba et al., 1978; Figueiredo et al., 1985: Dzau et al. 1979; Yokosawa et al., 1978; Yokosawa, 1980; Hirose, 1982; Pickens et al., 1965). The neutral $\mathrm{pH}$ is necessary to show its activity in plasma. The renin gene is also expressed in other tissues such as adrenal gland, gonads, placenta, pituitary, brain and hypothalamus (Hirose et al., 1978; Naruse et al., 1981, 1982; Pandey et al., 1984; Deschepper et al., 1986; Dzau et al., 1987; Paul et al., 1987; Suzuki et al., 1987; Tada et al., 1989). These extra renal renins have been thought to play a part in the tissue renin-angiotensin system proposed by several investigators (de Mello, 1995; van Kesteren et al., 1997; Admiraal et al., 1999; de Lannoy et al., 1997, 1998; Hokimoto et al., 1996; Sun et al., 1994; Danser et al., 1992, 1994; Neri Serneri et al., 1996; Campbell et al., 1993; Yusuf et al., 1991: Ruzicka et al., 1994; Schieffer et al., 1994; Van Gilst et al., 1984; Bickerton and Buckley et al., 1961; FischerFerraro et al., 1971; Ganten et al., 1971).

Removal of the 23 amino acid residues from the C-terminus of preprorenin generates prorenin. Prorenin (45-47 kDa containing 406 amino acid residues), the pre-active form of renin, is predominantly synthesized by granular cells of the juxtaglomerular apparatus (JGA) in the terminal afferent arteriole (Schnermann \& Briggs, 2008; Schweda et al., 2007) and principle cells of the collecting ducts (Prieto-Carrasquero et al., 2004; Rohrwasser et al., 1999; Kang et al., 2008). Prorenin is also synthesized in many other tissues like adrenal glands (Ganten et al., 1974, 1976; Ho and Vinson, 1998), zona glomerulosa (Doi et al., 1984; Deschepper, et al., 1986; Brecher et al., 1989), eye, Müller cells, mast cells (Krop et al., 2008), ovarian follicular fluid (Glorioso et al., 1986), and theca cells (Do et al., 1988), uterus (Derkx et al., 1987; Itskovitz et al., 1987), myometrium/decidual cells (Shaw et al., 1989), placenta (Lenz et al., 1991), chorionic cells, testis and leydig cells (Sealey et al., 1988). The submandibular gland in some mice strains produces a large amount of renin, which is a product of the Ren-2 renin gene distinct from the renal renin gene, Ren-1 (Cohen et al., 1972; Wilson et al., 1981; Holm et al., 1984) and this action is mediated by prorenin converting enzyme present in submandibular gland of the same mice strains (Kim et al., 1991). Prorenin, in the juxtaglomerular cells of the kidney, is converted to mature renin by the limited endoproteolysis after paired basic residues, Lys-Arg to remove the 43-amino acid residues containing prosegment sequence. The concentration of prorenin in human plasma 
is 10 times higher than that of mature renin though the physiological role of prorenin is still not clear and the relative concentration of prorenin to renin varies at different conditions. Thus, conversion of prorenin i.e., activation of prorenin to renin plays important role in the regulation of RA system. Certain proteases like trypsin or cathepsin were found to activate prorenin by cleaving the residue prosegment reversibly (Inagami et al., 1980; Shinagawa et al., 1990, 1994; Kikkawa et al., 1998; Jutras et al., 1999; Taugner et al., 1985; Wang et al., 1991; Jones et al., 1997). However, many tissues store prorenin but do not process it to active renin. Though extra-renal sources of prorenin are evident, kidney is the major source of plasma prorenin. Renin and prorenin have long been considered as the separate mediators of tissue and circulating systems (Sealy \& Rubattu, 1989). In vitro, when prorenin is acidified at $\mathrm{pH} 3.3$ or exposed to low temperature $\left(<4^{\circ} \mathrm{C}\right)$ or allowed to interact with antibodies designed from its prosegment sequences (protein-protein interaction), it mediates intrinsic catalytic activity without removal of the prosegment sequence from its $\mathrm{N}$-terminus through a reversible change in conformation (Derkx et al., 1979, 1983, 1987a \& b, 1992; Pitarresi et al., 1992, Suzuki et al., 2000, 2003).

Both renin and non-proteolytically activated prorenin catalyze angiotensinogen, a $6 \mathrm{kDa}$ protein macromolecule found also in adipose tissues to generate a small decapeptide called angiotensin I. Both neonatal and adult rat cardiac cells express mRNA for angiotensinogen (Dostal et al., 1992; Malhotra et al., 1994; Zhang et al., 1995; Liang et al., 1998; Sadoshima et al., 1993), while van Kesteren and colleagues (1999) were unable to detect angiotensinogen in neonatal rat cardiac cells or in the conditioned medium of these cells using radioimmunoassay. Secreted angiotensinogen in the cultured medium of neuronal cells has been identified. Generated renin product, angiotensin I thus, further converted into angiotensin II by the action of ACE.

The (pro)renin receptor or $(\mathrm{P}) \mathrm{RR}$ is now considering as another important regulatory component in renin-angiotensin system. However, ongoing research works have revealed its association both in angiotensin II-dependent and -independent pathways which also play pivotal role in the developmental processes.

\section{2. (Pro)renin receptor, a new family member of renin angiotensin system}

It's been almost a decade since the full length (pro)renin receptor or (P)RR was cloned (Nguyen et al., 2002). However, earlier the same group (Nguyen et al., 1996, 1998) reported high affinity binding of ${ }^{125}$ I renin to primary and immortalized human mesangial cells $(0.2$ and $1.0 \mathrm{nM}$, respectively) in a time-dependent fashion that could attain saturable state. The (P)RR does not internalize the ligands inside the cells rather activates renin and prorenin after binding to generate angiotensin I and second messenger pathway by activating proteins involved in signaling. In the late nineties of the last century, the mannose 6phosphate/insulin-like growth factor II (M6P/IGF2) receptor was found on rat cardiac myocytes (van Kesteren et al., 1997) and human endothelial cells (Admiraal et el., 1999; Saris et al., 2001) that could bind and internalize renin/prorenin (van Kesteren et al., 1997). However, such binding and internalization could not generate any angiotensin peptides intracellularly. Besides, existence of renin/prorenin receptor independent of mannose 6phosphate such as renin binding protein (RnBP), renin/prorenin binding protein (ProBP) in rat tissues, vascular renin binding protein have also been confirmed (Takahashi et al., 1983; 
Tada et al., 1992; Campbell et al., 1994; Sealy et al., 1996) that bind with different binding affinities to their ligands.

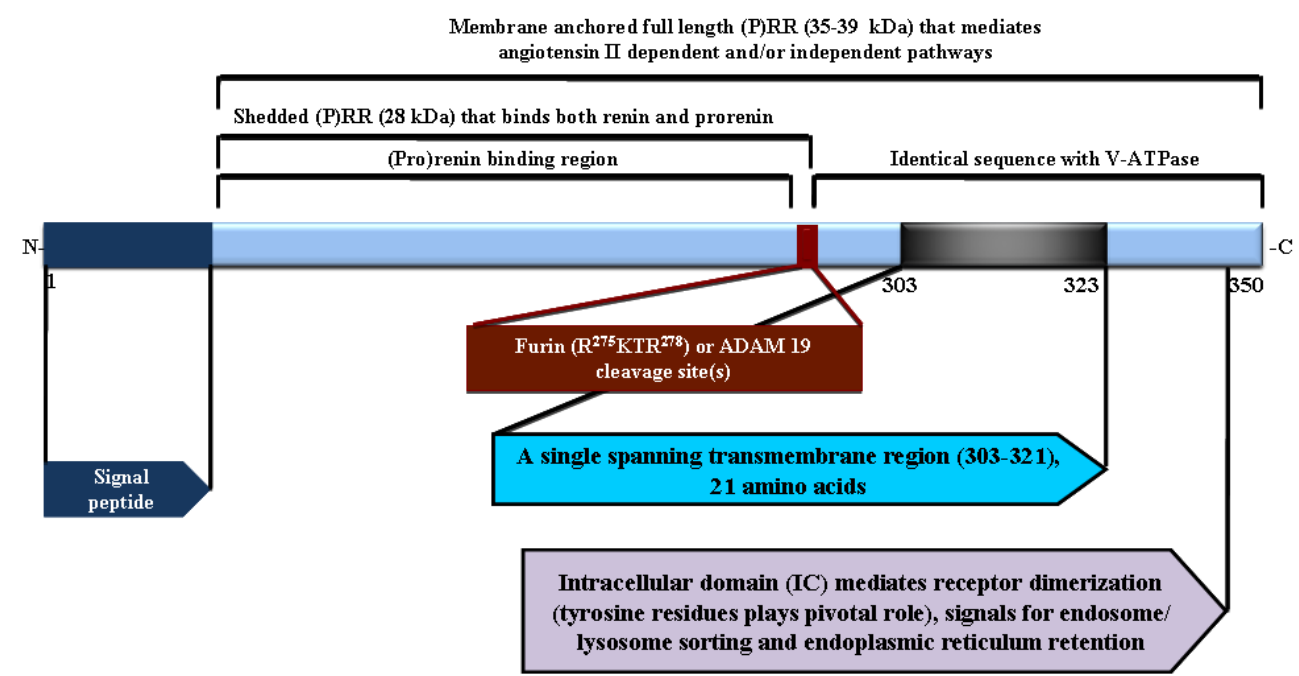

Fig. 2. Structure of (pro)renin receptor protein. The receptor protein is composed of three basic constituents with an N-terminal domain, which is the (pro)renin binding site, a single spanning transmembrane sequence that traverse through the plasma membrane and the intracellular cytoplasmic domain that recently has been identified as the important region required for the dimerization of $(\mathrm{P}) \mathrm{RR}$.

The (P)RR, expressed on the cell surface, is a 350 amino acid ( $39 \mathrm{kDa}$ ) containing protein with a single spanning transmembrane domain encoded from the $\mathrm{X}$-chromosome. A short signal peptide is present at the $\mathrm{N}$-terminus end of the unglycosylated large extracellular domain with $\sim 310$ residues and the transmembrane domain has putative 20-amino acid residues followed by a $\sim 19$-amino acid containing intracellular cytoplasmic (IC) domain (shown in Figure 2). Ubiquitous expression of (P)RR has been demonstrated with the highest amount of mRNA found in brain, heart and placenta while lower amount was expressed in liver, pancreas and kidney (Nguyen et al., 2002). It is reported that (P)RR expressed in VSMCs in human (P)RR transgenic rats can be recycled between intracellular compartment and cell membrane (Batenburg et al., 2007). The (P)RR is also localized on the membrane of stromal adipose cells (Achard et al., 2007), in the neurons of neonatal rats (Shan et al., 2008), on COS-7 cells (Nabi et al., 2007), in glomerular mesangial cells, the subendothelium of renal arteries, podocytes, and distal nephron cells (Nguyen et al., 2002, 1996, 1998) of human and rat kidneys; U937 monocytes (Feldt et al., 2008b) and also in intracellular compartments or on the surface of vascular smooth muscle cells (VSMCs) (Sakoda et al., 2007; Zhang et al, 2008), in endoplasmic reticulum (Schefe et al., 2006; Yoshikawa et al., 2011), golgi apparatus (Contrepas et al., 2009; Yoshikawa et al., 2011), cytosol (Contrepas et al., 2009; Cousin et al., 2009) and found in plasma (Cousin et al., 2009). Expression of (P)RR is also categorized in the subfornical organ (SFO), paraventricular nucleus, the supraoptic nucleus, the nucleus of the tractus solitarius (NTS), or the rostral 
ventrolateral medulla regions of brain that were believed to be involved in the central regulation of cardiovascular function and volume homeostasis (Contrepas et al., 2009), in the frontal lobe of human brain and pituitary (Takahashi et al., 2010). Retina is also a source of (P)RR (Satofuka et al., 2009). In particular, it is localized to pericytes in retinal vessels, endothelial cells, and, mostly in retinal ganglion cells and glia (Wilkison-Berka et al., 2010). Moreover, predominant expression of (P)RR using immunohistochemistry and in situ hybridization on the epical membrane of acid secreting cells in the collecting duct has been reported (Advani et al., 2009).

Full length rat and human recombinant $(\mathrm{P}) \mathrm{RR}$ with transmembrane followed by cytoplasmic domains were expressed in baculovirus expression system, and identified in the cellular fraction (Nabi et al., 2006; Du et al., 2008; Kato et al., 2008). On the other hand, human (P)RR containing only the extracellular domain lacking transmembrane part was found secreted in the culture medium (Kato et al., 2009). Also, human (P)RR was successfully expressed in the Bombyx mori multiple nucleopolyhedrovirus (BmMNPV) and found in the silkworm larvae as well as in the fat body of silkworm larvae. ELISA and surface plasmon resonance technique in BIAcore assay system confirmed the renin/prorenin binding ability i.e., the functional bioactivity of (P)RR expressed and fractionated from silkworm and baculovirus expression system (Nabi et al., 2006; Du et al., 2008; Kato et al., 2008, 2009).

A protease called furin was found to be responsible for shedding of endogenous (P)RR in trans-golgi by cutting at positions $\mathrm{R}^{275} \mathrm{KTR}^{278}$ near the N-terminus of transmembrane sequence (Cousins et al., 2009). This soluble form of (P)RR [s(P)RR, $28 \mathrm{kDa}$ ] was detected in the conditioned cultured medium and also in human plasma using co-precipitation experiment with human renin. Another protease ADAM19 sheds intracellular (P)RR from golgi apparatus into the extracellular space (Yoshikawa et al., 2011). Moreover, constitutively secreted soluble form of $(\mathrm{P}) \mathrm{RR}(\sim 30 \mathrm{kDa})$ shedded from the cell surface was found in the cultured medium of human umbilical vein endothelial cells (HUVECs) (Biswas et al., 2011) that could also bind recombinant human prorenin with a nanomolar order, similar to what was reported for full length (P)RR on the cell surface (Nguyen et al., 2002; Batenburg et al., 2007; Nurun et al., 2007) or from the baculovirus expression system (Nabi et al., 2006). Non-proteolytic activation of prorenin occurred when it interacted with s(P)RR in the soluble phase and this was confirmed by Western blot analysis. Also, activated prorenin showed renin activity by generating Ang I from sheep angiotensinogen (Biswas et al., 2011). However, the enzymatic properties of renin after binding to $(P) R R$ is yet to be determined. These phenomenons have been depicted in Figure 3 (vi).

C-terminal domain of (P)RR is identical to "M8-9," a truncated protein of $8.9 \mathrm{kDa}$ that copurified with a proton-ATPase of bovine chromaffin granule membranes (Ludwig et al., 1998). At the gene level (P)RR from human, rat, and mice showed 95\% sequence homology, while at the amino acid level they showed $80 \%$ homology. Phylogenetic analyses also revealed that the sequences for $(\mathrm{P}) \mathrm{RR}$ are not only conserved within the closely related species but also similar sequences are present in the remote species. The IC-domain of $(P) R R$ mediates the signal transduction pathways and promyelocytic zinc finger (PLZF) protein has been identified as an associated protein that interacts with the IC-domain to down regulate expression of the receptor. (P)RR has also been reported to exist as a dimer in vivo (Schefe et al., 2006). Recent evidences suggest that short and relatively flexible loop of IC 
segment generates the driving force in the process of dimerization of $(P) R R$ and tyrosine residues of IC contribute in dimerization dominantly (Zhang et al., 2011).

\section{1 (Pro)renin receptor and its ligand: interaction of (pro)renin with (pro)renin receptor}

Interaction of renin and prorenin with (pro)renin receptor instigates two pathways: one leads to generation of angiotensin II that ultimately contribute to the activation of local RA system via angiotensin II-dependent pathway as in case of classical circulating RA system and the other one leads to signal transduction mediated by angiotensin II-independent pathway outlined in Figure 3.

\subsubsection{Binding mechanism and activation of renin angiotensin system}

Binding of human renin to human $(\mathrm{P}) \mathrm{RR}$ increases local angiotensin production as it is manifested by the increased (4/5-fold) substrate affinity of (P)RR-bound renin compare to free form of soluble renin (Nguyen et al., 2002). On the other hand, human renin bound to recombinant human/rat (P)RR and free form of soluble renin showed similar binding affinity for the substrate, sheep angiotensinogen at the micromolar order (Nabi et al, 2006; Nurun et al., 2007). However, kinetic data analyses revealed that prorenin preferentially binds to (P)RR and such binding initiates angiotensin I generation (Nabi et al., 2006; 2009b). Full length rat $(\mathrm{P}) \mathrm{RR}$ expressed and isolated from the baculovirus expression system had almost 3 times higher binding affinity $\left(K_{D}=8.0 \mathrm{nM}\right)$ for rat prorenin than that of mature rat renin $\left(K_{\mathrm{D}}=20.0 \mathrm{nM}\right)$ in vitro (Nabi et al., 2006). Receptor-bound rat prorenin also had similar affinity for the substrate $\left(K_{\mathrm{m}}=3.3 \mu \mathrm{M}\right)$ sheep angiotensinogen as it was for rat renin. On the other hand, receptor-bound renin showed higher molecular activity (10 $\mathrm{nM} h)$ compared to free form of mature renin and receptor-bound activated prorenin (1.25 and $1.1 \mathrm{nM} h$ ) (Nabi et al., 2006).

Ninety\% of rat and fifty\% of human prorenin (at $2.0 \mathrm{nM}$ of initial concentration) bound to their respective $(\mathrm{P}) \mathrm{RR}$ over expressed on the membrane of COS-7 cells and the $K_{\mathrm{D}}$ s were estimated to be 0.89 and $1.8 \mathrm{nM}$, respectively. Receptor-bound rat and human prorenin showed $30 \%$ and $40 \%$ activity, respectively, in comparison with the activity of trypsinized prorenin molecules (Nurun et al., 2007). A similar binding and activation patterns of prorenin to human (pro)renin receptor expressed in VSMCs of transgenic rats $\left(K_{\mathrm{D}}=6.0 \mathrm{nM}\right)$ (Baternburg et al., 2007) and of rat prorenin by rat (P)RR expressed in cultured VSMCs were observed (Zhang et al., 2010). Differences in the $K_{\mathrm{D}}$ values of rat prorenin bound to the immobilized receptors on the synthetic surfaces and the membrane-anchored receptor could be due to the presence of some other associated proteins that might have stabilized the $(\mathrm{P}) \mathrm{RR}$ on the membrane. Surface plasmon resonance technique in BIAcore assay system revealed almost four times higher binding affinity of human prorenin $(1.2 \mathrm{nM})$ to the in vitro synthesized human recombinant $(\mathrm{P}) \mathrm{RR}$ compared to that of human mature renin $(4.4 \mathrm{nM})$ (Nabi et al., 2009b). The immobilized receptors bind recombinant human renin and prorenin with the dissociation constant $\left(K_{\mathrm{D}}\right)$ values of 1.2 and $4.4 \mathrm{nM}$, respectively. Also, the data obtained from the BIAcore kinetic study showed that association rate of prorenin to $(\mathrm{P}) \mathrm{RR}$ is higher than that of mature renin $\left(1.8 \times 10^{7}\right.$ and $2.16 \times 10^{6} \mathrm{M}^{-1} . \mathrm{s}^{-1}$, respectively) (Nabi et al., 2009b). 
The binding mechanism of renin and prorenin to the (pro)renin receptor has also been proposed depending on the ground work led by Suzuki and colleagues who demonstrated the importance of "handle" ([11PFLKR $\left.{ }^{15 P}\right)$ and "gate" (T7PFKR $\left.{ }^{10 P}\right)$ region peptides designed from the prosegment sequence of prorenin in the non-proteolytic activation of prorenin via protein-protein interaction (Suzuki et al., 2003). Later, another peptide called "decoy" (R10PIFLKRMPSI19P including the "handle" sequence) that mimics the N-terminus sequence of human prorenin prosegment showed its high binding affinity to the recombinant $(\mathrm{P}) \mathrm{RR}$ and this affinity explains the probable reason for high binding affinity of prorenin for $(\mathrm{P}) \mathrm{RR}$. Decoy peptide has got binding affinity to $(\mathrm{P}) \mathrm{RR}$ at the nanomolar order similar to that of prorenin (Nurun et al., 2007; Nabi et al., 2009a, 2009b). Even after 28 days of administration, fluorescent tagged handle region peptide (HRP) was recognized in the renal glomeruli and tubular lumen (Ichihara et al., 2006a; Kaneshiro et al., 2007). However, a signal of these fluorescent molecules is from the intact form of HRP or not is still arguable. This argument becomes even stronger from the findings of Leckie and Bottrill (2011). They synthesized part of prosegment sequence, RIFLKRMPSIR (it contains an additional arginine residue at the C-terminus of the decoy) and its scrambled sequence (SRRMIFPIKLR) to find out a novel binding sites in human umbilical vein endothelial cells using liquid chromatography coupled with tandem mass spectrometry (LC-MS/MS). Finally, they concluded that the binding of the human prorenin peptide R10IFLKRMPSIR 20 to HUVEC proteins is not specific for amino acid sequence and probably involves a general peptide/protein uptake mechanism without detecting a specific prorenin prosegment binding sites (Leckie \& Bottrill, 2011). Moreover, decoy peptide containing fluorescent component (carboxyfluorescein) either at $\mathrm{N}$-terminus or $\mathrm{C}$ terminus showed different binding affinity for (P)RR compared to that of wild type decoy in vitro (Nabi et al., 2010). Recombinant (P)RR coupled to CM5 sensor chips in BIAcore assay system (Nabi et al, 2009a, 2009b), immobilized on synthetic surfaces (Nabi et al, 2009b), (P)RR over expressed on COS-7 cells (Nurun et al, 2007) have revealed that decoy inhibits binding of renin/prorenin to $(\mathrm{P}) \mathrm{RR}$. The inhibitory constant $\left(K_{\mathrm{i}}\right)$ for the peptide was found at the nanomolar order. Also, subsequent in vivo studies have been carried out to show beneficial role of decoy peptide in ameliorating the end-stage organ damage related disorders by abolishing non-proteolytic activation of prorenin via inhibition of prorenin binding to (P)RR (Ichihara et al., 2004; 2006b \& c; Kaneshiro et al., 2007; Satofuka et al., 2006, 2007, 2009; Wikinson-Berka et al., 2010).

Interestingly, decoy peptide has also been found to inhibit binding of renin to $(\mathrm{P}) \mathrm{RR}$ and this action of decoy on renin is yet to be clarified. Based on these annotations and on the tertiary structure of renin as well as predicted tertiary structure of prorenin, the possibility of having a common site in both renin and prorenin through which these molecules can interact with the $(\mathrm{P}) \mathrm{RR}$ other than the decoy peptide sequence was hypothesized. A new sequence $\left(\mathrm{S}^{149}\right.$ QGVLKEDVF158) that localizes in the flexible junctional region between the N- and Cdomains of renin/prorenin termed as the "hinge" has recently been reported to have such pivotal role for renin/prorenin binding to (P)RR (Nabi et al., 2009b). The $K_{\mathrm{D}}$ for the binding of the "hinge" peptide to (P)RR was five times higher than that of the decoy and estimated to be $17 \mathrm{nmol} / \mathrm{L}$. The "hinge" showed higher binding affinity to the (P)RR than that of another peptide $\left(\mathrm{A}^{248} \mathrm{KKRLFDYVV}{ }^{257}\right.$ ) from the C-domain of renin/prorenin molecule,. Like the decoy, "hinge" peptide also reduced the resonance signal of renin/prorenin binding to $(\mathrm{P}) \mathrm{RR}$ as observed in BIAcore, and equilibrium state analysis revealed this paradigm as a 
competitive inhibition with the $K_{\mathrm{i}}$ of 37.1 and $30.7 \mathrm{nmol} / \mathrm{L}$, respectively (Nabi et al., 2009b). Therefore, these data suggest that not only the decoy peptide but also the "hinge" region peptide together accounted for the higher binding affinity of prorenin and hence, prorenin molecule has at least two high affinity sites while renin has a single site for their binding to (P)RR. Considering the nanomolar binding affinities of renin/prorenin and handle region peptide, Duncan J Campbell in one of his review article suggested that the (pro)renin receptor may have at least two separate binding domains, one domain is for renin and the other one is for prorenin prosegment and/or HRP (Campbell, 2008). Though, prorenin has two regions to interact with $(\mathrm{P}) \mathrm{RR}$, but to confirm the existence of different binding sites within $(\mathrm{P}) \mathrm{RR}$ for its ligands, three dimensional structure of $(\mathrm{P}) \mathrm{RR}$ has to be elucidated.

Activation of renin angiotensin system or in other words, generation of Ang-I by (P)RR mediated non-proteolytically activated prorenin depends on the sources of prorenin. Human prorenin showed higher binding affinity to both human and rat $(\mathrm{P}) \mathrm{RR}$ compared to that of rat prorenin (Biswas et al., 2010a). More interestingly, either bound to human or rat (P)RR, molecular activity of non-proteolytically activated human prorenin was 2-4 fold higher than that of rat prorenin (Biswas et al., 2010), which could be due to the slow activation rate through change in conformation of rat prorenin compared to that of human prorenin after protein-protein interaction. Contribution of prorenin prosegment in the nonproteolytic activation mechanism was reported earlier in vitro (Suzuki et al., 2000). Chimera of human renin and rat prosegment showed very slow activation like native rat prorenin compared to the chimera of rat renin and human prosegment. Thus, it could be proposed that the prosegment sequence of prorenin played a pivotal role for the activation of prorenin molecules. More concisely, species specific regions within the prorenin prosegment like "handle" (Nurun et al., 2007; Suzuki et al., 2003) and decoy peptides (Nurun et al., 2007; Nabi et al., 2009a, b) actually crucial for the interaction of prorenin with (P)RR and also, for the non-proteolytic activation mediated by protein-protein interaction. Activation of rat prorenin through change in conformation at acidic condition required long time, even days to month (Suzuki et al., 2000). However, (P)RR mediated activation of rat prorenin has been observed within hours using recombinant $(\mathrm{P}) \mathrm{RR}$ on in vitro synthetic surface system (Nabi et al., 2006; Biswas et al., 2010a) or overexpressing (P)RR on COS-7 cells (Nurun et al., 2007) or on rat VSMCs (Batenburg et al., 2007; Zhang et al., 2008). This might be the result of quick conformational change of prosegment of rat prorenin exerted by the interaction of one protein (receptor) with the other (ligand).

Furthermore, while cosidering the binding mechanism of renin and prorenin to their receptor, (P)RR has not only been discussed from the ligand's point of view, rather primary structure of (P)RR has also got similar attention for explaining the possible mechanism of receptor's involvement in ligand binding. On the other hand, though three dimensional (3D) structure of renin (Dhanaraj et al., 1992) and a predicted 3D model of prorenin (Suzuki et al., 2003; Nabi et al., 2009b) are available but due to lack of 3D structure of the receptor, mechanism for interaction of (pro)renin can not be explained from the receptor's point of view. However, several anti-(P)RR antibodies designed from the middle part (107DSVANSIHSLFSEET121 named as anti-107/121 antibody) and C-terminus [221EIGKRYGEDSEQFRD ${ }^{235}$ and 237SKILVDALQKFADD250; close to the N-terminus of transmembrane region of the receptor, named as anti-221/235 and 237/250 antibodies, respectively] regions of (pro)renin receptor have been used in many studies (Nabi et al, 2009a, 2009b; Nabi et al., 2012). Depending on the 
flexibility of the anti-(P)RR antibody associated (pro)renin receptor, it would show its binding affinity towards the ligands. The calculated binding affinities of prorenin were $2.9 \times 10^{-9}, 1.2 \times 10^{-9}$ and $1.74 \times 10^{-9} \mathrm{nM}$, when (P)RR was immobilized or occupied by anti-107/121, anti-221/235 (Nabi et al, 2009a, 2009b) and 237/250 antibodies (Nabi et al., 2012), respectively. The recombinant $(\mathrm{P}) \mathrm{RR}$ tagged with six histidine residues was synthesized in a cell free in vitro system using wheat germ lysate. It was hypothesized that the His tag sequence at the Cterminal end would retain the transmembrane characteristics of $(\mathrm{P}) \mathrm{RR}$ in vitro. So, $(\mathrm{P}) \mathrm{RR}$ occupied by the anti-His tag antibody would indicate its native binding pattern while interacting with the ligands. Study showed that the binding affinity of prorenin to anti-His tag antibody-bound (P)RR was 7.8 nM (Nabi et al., 2009a) and other studies using over expressed (P)RR on the cell surface showed comparable nanomolar order of binding affinity of prorenin to (P)RR (Nguyen et al., 2002; Nurun et al., 2007; Batenburg et al., 2007). Reports available so far indicate that binding region for prorenin within $(\mathrm{P}) \mathrm{RR}$ resides possibly further upstream region of the amino acid residue at position 107, which could be more close to the N-terminal region(s) of the receptor.

\subsubsection{Initiation of second messenger pathways}

Binding of renin/prorenin to $(\mathrm{P}) \mathrm{RR}$ initiates an intracellular signaling pathway that is independent of angiotensin II mediated pathway. Both renin and prorenin stimulated $\mathrm{p} 42 / \mathrm{p} 44$ mitogen-activated protein kinase (MAPK) or ERK1/2 that leads to up-regulation of transforming growth factor- $\beta 1$ release in mesangial cells, PAII, collagens, fibronectin (Huang et al, 2006; Huang et al, 2007; Sakoda et al, 2007) and cyclooxygenase 2 (Kaneshiro et al., 2006; Nguyen, 2006) as shown in Figure 3 (ii). Moreover, prorenin also activated p38 mitogen-activated protein kinase and simultaneously phosphorylate heat-shock protein-27 in cardiomyocytes (Sasris et al., 2006). Prorenin and renin induced activation of extracellular protein kinases (ERK) 1/2 in monocytes has also been reported (Feldt et al., 2008b). In the kidneys of diabetic mice, activation of all the three members of MAPK family including ERK, p38 and c-Jun $\mathrm{NH}_{2}$-terminal kinase (JNK) was observed (Ichihara et al., 2006a), whereas another report (Sakoda et al., 2007) revealed activation of ERK not p38 and JNK upon activation of $(\mathrm{P}) \mathrm{RR}$ via its ligand, prorenin. A protein called promyelocytic zinc finger (PLZF) has also been identified and this has been found to be associated with the cytoplasmic domain of the receptor (Schefe et al. 2006). Binding of prorenin to the receptor drives translocation of PLZF to the nucleus by stimulating P13K p85 pathway that ultimately generates short negative feedback loop to down regulate (P)RR expression [depicted in Figure 3 (iii)]. Furthermore, (P)RR is a component of the Wnt [wingless-type mouse mammary tumor virus (MMTV) integration site family] receptor complex. Wnt proteins are highly conserved secreted signaling molecules and regulators of multiple biological and pathological processes (Logan and Nusse, 2004). The signaling mechanism mediated by Wnt receptor in conjunction with (P)RR and $\mathrm{H}^{+}$-VATPase has been explained in detail later in this chapter. The detail of the intracellular signaling pathway activated and mediated by the (pro)renin receptor has been depicted and categorically presented in Figure 3.

\section{Pathophysiology of prorenin and (pro)renin receptor}

Hepatocyte specific prorenin transgenic rat revealed direct pathophysiological action of prorenin. Prorenin is not activated in liver and less than $2 \%$ of the total circulating prorenin 
found to be active in plasma. Diabetic subjects with microalbuminuria had very high prorenin to renin ration. Before the onset of microalbuminuria levels of prorenin begins to increase, and in conjunction with the glycated haemoglobin, the prorenin levels in plasma could be used to predict the occurrence of later microalbuminuria (Deinum et al., 1999). The circulating prorenin is responsible for developing hypertrophy of cardiomyocytes, glomerulosclerosis and atherosclerosis of small to medium sized artery, indicating elevated prorenin itself causes cardiomyopathy, glomerulosclerosis and atherosclerosis. Use of angiotensin converting enzyme inhibitors and angiotensin-II type 1 receptor blockers play protective role in end-stage organ damage in patients with hypertension and diabetes by suppressing the circulating RA system. Yet, low amount of renin activity is still evident in the plasma of these under treatment diabetic and hypertensive subjects which could ultimately be attributed to the enhanced tissue RA system. Thus, reasons behind the direct involvement of prorenin in the pathology of hypertension, diabetes and heart failure remained unclear. Receptor- associated prorenin system (RAPS), a novel phenomenon, sheds light on this direct action of prorenin. (P)RR, the new member of the RA system, has set a new perception about the physiological functions, activation mechanism and pathophysiological roles of renin/prorenin by activating angiotensin II-dependent or independent pathways [Figures 3 (i), (ii), (iii)]. It has its own intracellular signalling pathways. Non-proteolytic activation of prorenin after interacting with (P)RR hypothesized that this activation mechanism of prorenin plays a pivotal role in the regulation of tissue RA system and end-organ damage in diabetic animals. (P)RR mRNA and protein expression are up-regulated in the hearts and kidneys of rats with congestive heart failure (Hirose et al., 2009). Thus, (P)RR in the heart can act as a capturing molecule for renin/prorenin which ultimately explain the presence of local renin-angiotensin system in heart, which can't synthesize renin. In diabetes, enhanced activity of oxidative stress and AT1 receptor are associated with up-regulation of (P)RR and this could be suppressed using AT1 receptor blocker and NADPH-oxidase activity inhibitor (Siragy and Huang, 2008). (P)RR mediated stimulation of signal cascade (depicted in Figure 3 ) of transforming growth factor- $\beta 1$ (TGF$\beta 1$ ) and connective tissue growth factor (CTGF) in renal glomeruli (Huang et al., 2011) and enhancement of renal production of the inflammatory cytokines- TNF-alpha and IL-1beta, independent of the effects of renal Ang-II (Matavelli et al., 2010), contributes to the development and progression of kidney disease in diabetes. Up-regulation of $(\mathrm{P}) \mathrm{RR}$ expression by high glucose is mediated by both PKC-Raf-ERK and PKC-JNK-c-Jun signaling pathways. Also, nuclear factor- $\mathrm{KB}$ and activation protein-1 are involved in high-glucoseinduced (P)RR up-regulation in rat mesangial cells (Huang and Siragy, 2010).

At 5-6 months of age, transgenic rats over expressing the human (P)RR gene nonspecifically developed glomerulosclerosis with proteinuria by three to seven times without elevating the blood pressure (Kaneshiro et al., 2007). Transgenic rats over expressing human (P)RR gene exclusively in smooth muscle cells developed hypertension at their 7 months of age (Burckle et al., 2006). (Pro)renin receptor mediated non-proteolytically activated prorenin contributes to the development and progression of nephropathy including proteinuria and glomerulosclerosis in diabetic animals with high plasma levels of prorenin by increasing angiotensin II tissue generation (Ichihara et al., 2004). An increased Ang-I content was observed in the heart of double transgenic mice over expressing human prorenin and angiotensinogen compared to the single-transgenic mice (Prescott et al., 2002). These results indicate how prorenin contribute to the generation of angiotensin peptides locally and tissue 


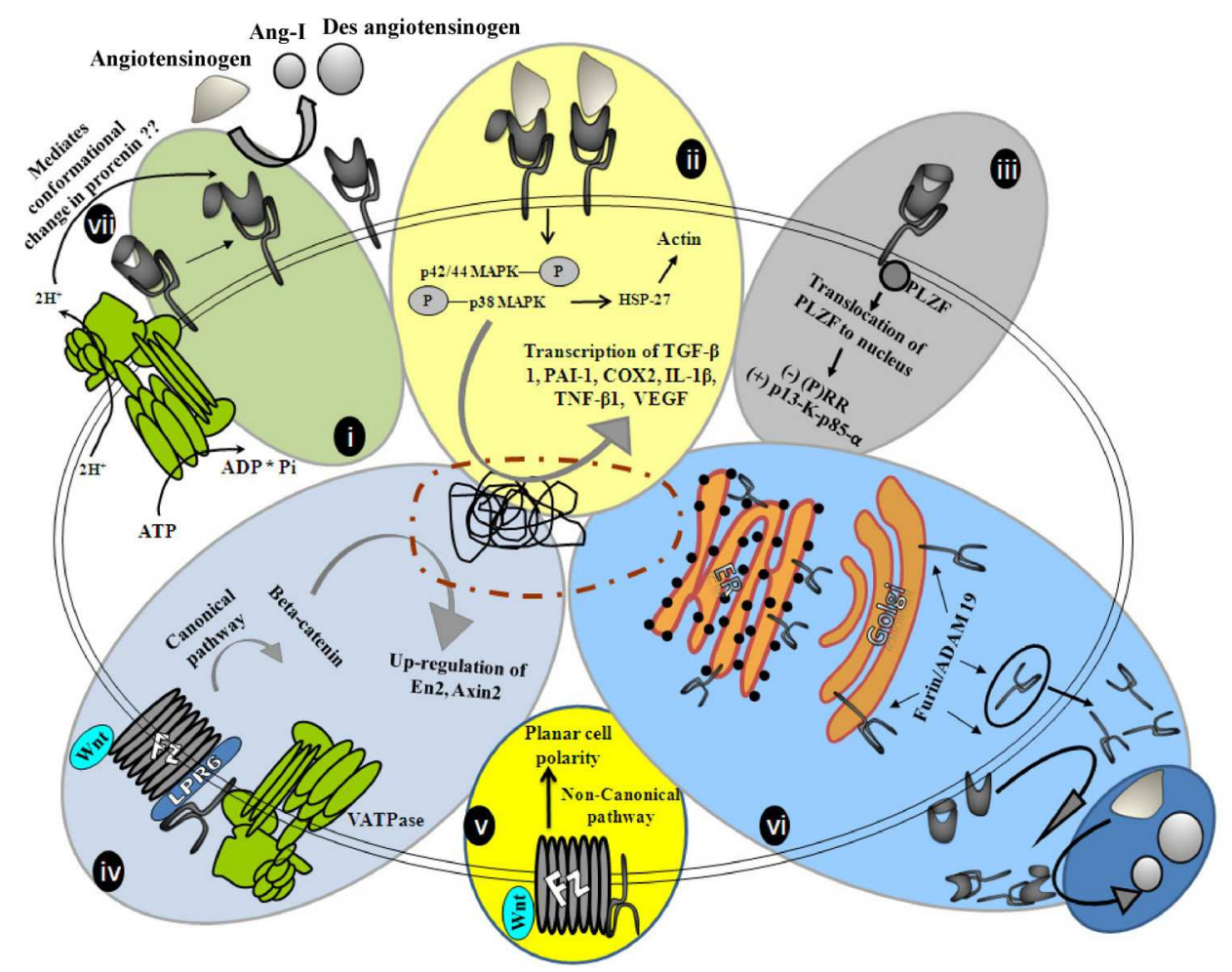

Fig. 3. Receptor associated prorenin system or RAPS mediated by prorenin and (pro)renin receptor $[(P) R R]$ has set a new perception about the involvement of renin-angiotesin system in the pathophysiology of end-stage organ damage. Such nomenclature has been proposed due to the dual activation of tissue RAS (i) and RAS-independent signaling pathways (ii-vii). Augmentation of tissue RAS or RAPS via (P)RR initiates endocrine, paracrine or autocrine activities mediated by angiotensin II peptide. Binding of renin/prorenin to $(\mathrm{P}) \mathrm{RR}$ initiates signal transduction via angiotensin II independent pathway by activating mitogen activated protein kinases (MAPKs) that induce expression of many regulatory proteins (ii).

Translocation of promyelocytic zinc finger (PLZF) after prorenin binding to (P)RR leads to a short negative feed back loop that in turn suppresses (P)RR expression (iii). Also, (P)RR itself, independent of renin/prorenin, mediates Wnt- $\beta$ catenine (canonical, iv) and Ez/PCP (non-canonical) signaling pathways (v). (P)RR can be processed in the golgi apparatus by Furin or ADAM19 to its soluble form (vi). The shedded (P)RR through exocytosis can come outside of the cell and has been detected in human plasma and cultured cell medium. Shedded (P)RR binds (pro)renin. Prorenin bound to soluble (P)RR performs enzymatic activity (vi). V-ATPase participates in proton transport. C-terminal region of $(P) R R$ is identical to the sequence of V-ATPase. This is not clear whether non-proteolytic activation of prorenin through conformational change after receptor binding is also mediated by the acidic environment created by membrane associated V-ATPase and (P)RR (vii). 
damage after being taken up by tissues from circulation. (P)RR is up-regulated in kidneys of diabetic rats and renal mesangial cells exposed to high glucose concentration (Siragy and Huang, 2008; Huang and Syragi, 2010). Rapid phosphorylation at the serine residues of (P)RR in response to hyperglycemia up-regulates TGF-beta1-CTGF cascade (Huang et al., 2011), which initiates or augments kidney disease in diabetic rats. An increased Ang-I content was observed in the heart of double transgenic mice over expressing human prorenin in the liver and human angiotensinogen in the heart as compared to the singletransgenic mice (Prescott et al., 2002). These results indicate how prorenin contribute to the generation of angiotensin peptides locally and tissue damage after being taken up by tissues from circulation. Moreover, (P)RR by stimulating non-proteolytic activation of prorenin contribute to the development of renal and cardiac fibrosis in spontaneously hypertensive rats (SHRs) (Ichihara et al, 2006a,b). These data demonstrated the possible involvement of $(\mathrm{P}) \mathrm{RR}$ in the pathogenesis of heart failure and kidney tissue damage. Association of $(\mathrm{P}) \mathrm{RR}$ gene polymorphism with high blood pressure and left ventricular hypertrophy substantiate the important role of (P)RR in the pathogenesis of hypertension in humans (Hirose et al., 2011; Ott et al., 2011) In vitro and animal studies have shown that increased receptor expression could be linked to high blood pressure and to cardiac and glomerular fibrosis by activating mitogen-activated protein kinases and by upregulating gene expression of profibrotic molecules. Also, animal studies with angiotensin-II type 1a receptor deficiency showed that the $(\mathrm{P}) \mathrm{RR}$ is involved in the development and progression of diabetic nephropathy through angiotensin-II independent pathway via activation of intracellular pathways (Ichihara et al., 2006c).

Association of prorenin and the (P)RR with the development of ocular pathology/diseases has been reported (Satofuka et al., 2006, 2007, 2008; Wikinson-Burka et al., 2011). Nonproteolytic activation of prorenin mediated by $(\mathrm{P}) \mathrm{RR}$ is associated with retinal neovascularization in experimental retinopathy model of prematurity (Satofuka et al., 2007). Using the same model, the involvement of prorenin and $(\mathrm{P}) \mathrm{RR}$ in the pathological angiogenesis, leukocyte accumulation and intracellular adhesion molecule- 1 with vascular endothelial growth factor expression; retinal gene and protein expression of inflammatory mediators has also been demonstrated (Satofuka et al., 2006, 2008). RILLKKMPSV, a peptide sequence of rat prorenin prosegment, influences the vasculature, glia and neurons, and (pro)renin receptor expression in the retina (Wikinson-Burka et al., 2011).

\section{Functions of $(P) R R$ other than its involvement in renin-angiotensin system}

The prototype of sequence homology between $(\mathrm{P}) \mathrm{RR}$ from human and other species actually gave a clue regarding its plausible additional role in biological processes other than RAS. Two or more genes homologous to $(\mathrm{P}) \mathrm{RR}$ have been found in C. elegans and Drosophila melanogaster that are phylogenetically distant from human. These species also express some components of RAS, which are not involved in homeostasis or electrolyte balance. Thus, (P)RR in these species may contribute to functions not related to RAS.

The C-terminal truncated fragment of (P)RR helps to assemble vacuolar $\mathrm{H}^{+}$-proton adenosine triphosphatase (V-H+-ATPase) (Ludwig et al., 1998). The (P)RR is also identical to endoplasmic reticulum-localized type 1 transmembrane adaptor precursor (CAPER) (Burckle \& Bader, 2006; Campbell, 2006; Bader, 2007; Strausberg et al., 2002). Evolutionarily 
$\mathrm{V}-\mathrm{H}^{+}$-ATPase is a highly conserved ancient enzyme in eukaryotic cells (Nelson et al., 2000) and this could be one of the most plausible reasons behind the sequence homology of Cterminus of human (P)RR with the evolutionarily close species like rat, mouse, chicken, drosophila, mosquito, zebra fish, frog and remote like C. elegans and bacteria Ehrlichia chaffeensis. (P)RR exists in truncated form composed of transmembarne region and the cytoplasmic tail that co-precipitates with V-ATPase may govern its function unrelated to RA system (Bader 2007). For this reason, (P)RR is also known as ATP6ap2 (adaptor protein type II vacuolar $\mathrm{H}^{+}$-ATPase). The $\mathrm{V}-\mathrm{H}^{+}$-ATPase is expressed in the collecting ducts and distal tubules within the kidney, where it contributes to the urinary acidification as well as play pivotal role in endocytosis (Toei et al., 2010). Different subunits of V-ATPase perform different functions, notably, mutations in genes encoding $C$ or D subunits in mice involved in embryonic lethality giving an evidence that V-ATPase plays an important role in development (Inoue et al, 1999; Miura et al, 2003), mutated B1 or A3 subunit involved in metabolic acidosis and osteoporosis in mice, respectively (Li et al., 1999; Finberg et al., 2005) and altered B1 or A4 subunit causes distal renal tubular acidosis in human (Karret, 1999; Smith, 2000). It is suggested that (P)RR and vacuolar $\mathrm{H}^{+}$-ATPase are linked together in the kidney (Advani et al., 2009) while, for the assembly and function of vacuolar $\mathrm{H}^{+}$-ATPase in the heart, (P)RR plays very pivotal roles (Kinouchi et al., 2010).

Recent evidences demonstrate that $(\mathrm{P}) \mathrm{RR}$ is a component of the Wnt receptor complex (Cruciat et al., 2010). It is essential for en 2 expression because of its requirement in Wnt signaling. It also acts down stream of Wnts and upstream of $\beta$-catenin [Figures 3 (iv) and (v)]. Deletion of the cytoplasmic domain of (P)RR, which mediates renin signaling inside cell, showed no effect on Wnt receptor binding suggesting that $(\mathrm{P}) \mathrm{RR}$ acts in a reninindependent manner as an adaptor between Wnt receptors and the V-ATPase complex. Moreover, malfunctioning (P)RR contributed to the abnormal tadpoles characterized by small heads, shortened tails, as well as defects in melanocyte and eye pigmentation at the early embryonic stage as $(\mathrm{P}) \mathrm{RR}$ and $\mathrm{V}$-ATPase are required to mediate Wnt signaling during antero-posterior patterning of Xenopus's early central nervous system development (Cruciat et al., 2010). A homologue of (pro)renin receptor in Drosophila [d(P)RR], localized mainly to the plasma membrane, has an evolutionarily conserved role at the receptor level for activation of canonical and noncanonical Wnt/Fz (frizzled) signaling pathways [Figure $3(\mathrm{v})$ ]. Attenuation of $\mathrm{d}(\mathrm{P}) \mathrm{RR}$ affects $\mathrm{Wg}$ target genes in cultured cells and in vivo (Buechling et al., 2010). Over expressed d(P)RR interacts with Fz and Fz2 receptors which is required for planar cell polarity in Drosophila epithelia and also for convergent extension movements in Xenopus gastrulae. Small interfering RNAs targeting human (pro)renin receptor significantly reduced Wnt-responsive TopFlash reporter activity in HEK293T cells. Thus, (P)RR has a conserved role in mediating Wnt signaling in human (Buechling et al., 2010). This data is also consistent with the findings of Cruciat et al (2010) who demonstrated the developmental role of (P)RR in Xenopus. Further, asymmetric subcellular localization of frizzled, a seven-pass transmembrane receptor that acts in both wingless $(\mathrm{Wg})$ and planar cell polarity $(\mathrm{PCP})$, is prerequisite for the proper functioning of PCP signaling pathway (Hermle et al., 2010). It has been demonstrated that the function of VhaPRR, an accessory subunit of the vacuolar (V)ATPase proton pump in Drosophila and also known as the VhaM8-9 because of its sequence homology with V-ATPase, is tightly associated with Fz but not to other PCP 
core proteins. Fz fails to localize asymmetrically in absence of VhaPRR. It also acts as the modulators of canonical Wnt signaling pathway in larval and adult wing tissues. VhaPRR knock down caused multiple wing hair and hair mispolarization phenotypes (Hermle et al., 2010). These indicate the association of (P)RR in non-canonical (Fz/PCP) signaling pathways. Recent evidences regarding the association of (P)RR with H+-ATPase and Wnt signaling pathway shedding light on the reason behind the connection of non-proteolytic activation of prorenin by $(\mathrm{P}) \mathrm{RR}$ with glomerulosclerosis, fibrosis, proteinuria. Though in vitro studies suggested non-proteolytic activation of prorenin mediated by $(\mathrm{P}) \mathrm{RR}$, but it is yet to determine whether the activation is mediated only by the protein-protein interaction, or by the co-operation of (P)RR and $\mathrm{V}-\mathrm{H}^{+}$-ATPase, or only due to the acidic environment created as a result of proton transport in vivo [Figure 3 (vii)]. However, because Wnt signaling pathway promotes renal fibrosis, glomerulosclerosis and proteinuria, (He et al., 2009; Dai et al., 2009) it is possible that (P)RR might act in a combination of $(\mathrm{P}) \mathrm{RR}-\mathrm{H}^{+}$-ATPase-Wnt signaling pathway. Thus, $(\mathrm{P}) \mathrm{RR}$ is involved in the Wnt/ $\beta$-catenin canonical and Wnt/PCP non-canonical pathways in conjunction with $\mathrm{V}-\mathrm{H}^{+}$-ATPase in a renin-independent fashion [Figures 3 (iv) and (v)].

Using zebra fish, the important association of (P)RR and V-ATPase in the development of brain and eye at the very early stage of embryonic development has been demonstrated (Amsterdam et al., 2004). A mutation in (P)RR is very lethal that causes death before the completion of embryonic stage by creating severe malformations of the central nervous system. In fact, while ACE is required to maintain fertility and ACE2 serves as a receptor for the SARS corona virus [causing factor for severe acute respiratory syndrome (SARS)], a single amino acid mutation in exon-4 of (P)RR mRNA associated with X-linked mental retardation and epilepsy (Ramser et al., 2005), and thus, (P)RR seems to be important for brain development and cognition. Also, another major finding (Contrepas et al., 2009) stated that $(\mathrm{P}) \mathrm{RR}$ play essential role in neuronal cell differentiation. Other than the embryonic development, $(\mathrm{P}) \mathrm{RR}$ gene polymorphism has been found to be associated with high blood pressure in Caucasian and Japanese male subjects (Hirose et al., 2011; Ott et al., 2011). Elevated blood pressure and increased heart rate in transgenic rats over expressing $(P) R R$ in smooth muscles have been reported in their models (Burckle et al., 2006).

\section{Inhibition of the activities of the components of renin angiotensin system: (pro)renin receptor as a new therapeutic target}

Peptides mimicking the structural part of prorenin prosegment (pro-enzyme of renin) or $\mathrm{N}$ terminal sequence of angiotensinogen containing the renin cleavage site were the firstgeneration of renin inhibitors (Boger et al., 1985; Hui et al., 1987; Bolis et al., 1987). Parenteral administration of these drugs efficiently reduced blood pressure by inhibiting renin activity in animals and in human being (Boger et al., 1985; Webb et al., 1985). However, due to their peptidic nature, these drugs had very poor oral bioavailability. Later, chemically modified CGP29287 achieved more attention as renin inhibitor due to its stability and longer duration of action when given orally (Wood et al., 1985). Further, development of other drugs like enalkiren (A 64662), CGP38560A, remikiren (Ro 425892) and zankiren (A 72517) with molecular weight of a tetra-peptide (Wood et al., 1994,1989; Maibaum et al., 2003) also failed to attract attention due to their low bioavailability $(<2 \%)$, a short half-life 
and weak blood pressure lowering activity when administered orally (Wood et al., 1994; Nussberger et al., 2002; Rongen et al., 1995). On the other hand, an orally inactive peptide from snake venom established the important role of angiotensin converting enzyme (ACE) inhibitors in regulating blood pressure. This led to the development of Captopril, the first ACE inhibitor. Moreover, blood pressure lowering activity, to a great extent, depends on the inhibiting ability of plasma renin activity (PRA) and/or reducing plasma renin concentration (PRC). Thus, use of ACE inhibitors or angiotensin receptor blockers (ARBs) for inhibiting renin angiotensin system is not as effective as it should be because these inhibitors ultimately increase PRA or PRC (Mooser et al., 1990; Azizi et al., 2004). In addition, inhibition of ACE increases angiotensin I, which would be, via ACE-independent pathways by using cathepsins and tonins, converted into angiotensin II (Wolny et al., 1997; Hollenberg et al., 1998). Together these data indicate that direct renin inhibitors could be the superlative choice as an anti-hypertensive agent which would lower plasma renin activity.

Aliskiren, an octanamide, the first known representative of a new class of completely nonpeptide, low-molecular weight, orally active transition-state renin inhibitor, that progressed to phase-III clinical trials (Wood et al., 2003). After oral dose of aliskiren (from 40 to $640 \mathrm{mg} /$ day) in healthy volunteers, its plasma concentration increased dose dependently and the peak concentration reached after 3-6 hour with an average half life of 23.7 hour (Nussberger et al., 2002) making the compound suitable for once-daily administration. The oral bioavailability was $2.7 \%$. Plasma steady-state concentrations were reached after 5-8 days of treatment. Aliskiren can inhibit enzymatic activities of receptor-bound renin and non-proteolytically activated prorenin, while it has no effect on the interaction of renin/prorenin with (P)RR. Also, aliskiren could not act as $(\mathrm{P}) \mathrm{RR}$ blocker to inhibit renin/prorenin binding to $(\mathrm{P}) \mathrm{RR}$ or failed to prevent (pro)renin signaling (Feldt et al., 2008b). Interestingly, when renin was incubated with aliskiren and then, allowed to bind to $(\mathrm{P}) \mathrm{RR}$, the binding affinity of renin to $(\mathrm{P}) \mathrm{RR}$ decreased more than 1000 fold in vitro (Biswas et al., 2010b).

Also, an ideal blocker for (pro)renin receptor is indeed a necessity of time considering the direct association of $(\mathrm{P}) \mathrm{RR}$ with increased blood pressure and its indirect involvement, via non-proteolytic activation of prorenin, in the pathogenesis of end-stage organ damage in hypertension, diabetes and ocular diseases. The efficacy of a peptidic blocker known as decoy peptide (R10PIFLKRMPSI19P) designed from the N-terminus of prorenin prosegment on the basis of the sequence of handle (I11PFLKR ${ }^{15 P}$ ) region peptide was reported earlier for improving organ damage (Ichihara et al., 2004). Both human and rat decoy peptides inhibited the bindings of human and rat prorenins to their respective (P)RR expressed on the membranes of COS-7 cells with a similar $K_{\mathrm{i}}$ of $6.6 \mathrm{nM}$ (Nurun et al., 2007). This peptide inhibited the bindings of not only prorenin but also renin to the preadsorbed receptors with the $K_{\mathrm{i}}$ values of 15.1 and $16.7 \mathrm{nM}$, respectively (Nabi et al., 2009b). Moreover, real-time bindings using surface plasmon resonance (SPR) technique in BIAcore assay system revealed evidence for the direct binding of native decoy peptide to the immobilized $(\mathrm{P}) \mathrm{RR}$ with $K_{\mathrm{i}}$ of $3.5 \mathrm{nM}$ (Nabi et al., 2009a, 2009b). The SPR technique displayed reduced resonance signal of prorenin binding to $(\mathrm{P}) \mathrm{RR}$ while co-incubated with the decoy peptide.

The decoy proposition has also been tested in vivo using various transgenic models. Administration of HRP significantly inhibited increased levels of renal angiotensin II, the development of proteinuria and glomerulosclerosis in a model of diabetic nephropathy; rat 
HRP completely prevented the development of diabetic nephropathy in heminephrectomized streptozotocin induced diabetic rats without affecting hyperglycemia (Takahashi et al., 2007). Urinary albumin excretion and the renal production of tumor necrosis factor- $\alpha$ and interleukine- $\beta 1$ were decreased significantly when rat HRP was given directly into the renal cortical interstitium of diabetic rats (Matavelli et al., 2010). Prevention of the development of proteinuria, glomerulosclerosis, and complete inhibition of the activation of ERK1/2, p38, JnK in the kidney of diabetic angiotensin-II type-1a receptordeficient mice was reported and thus, the role of (P)RR via angiotensin II independent pathway in association with prorenin was suggested (Ichihara et al., 2006c). Other investigators also confirmed the action of prorenin and (P)RR via angiotensin-II independent pathway (Huang et al., 2006; Muller et al., 2008; Feldt et al., 2008a, b). Moreover, HRP inhibits the development of retinal neovascularization by inhibiting nonproteolytic activation of prorenin caused by interaction with $(\mathrm{P}) \mathrm{RR}$ in experimental retinopathy model of prematurity (Satofuka et al., 2007). Satofuka et al. using the same model, showed that the HRP suppressed the pathological angiogenesis, leukocyte adhesion and retinal expression of ICAM-1 and VEGF; also, reduced retinal gene and protein expression of inflammatory mediators (Satofuka et al., 2006, 2009). HRP also improved vascular disorder in a model of retinopathy of prematurity, but had detrimental effects on retinal neurons and glia. These effects occurred despite HRP not being detected in plasma. In young spontaneously hypertensive rats (SHR) under high salt-diet, HRP not completely but significantly attenuated glomerulosclerosis with proteinuria, cardiac hypertrophy with left ventricular fibrosis without affecting the development of hypertension (Ichihara et al, 2006 a, b). In addition, Susic et al made a further interesting observation by reporting reduced beneficial effects of decoy (PRAM-1) in SHR rat with normal diet (Susic et al., 2008).

On the contrary, many researchers are not satisfied about decoy's role as a fruitful (P)RR blocker (Batenburg et al., 2007; Muller et al., 2008; Feldt et al., 2008a, b; Mercure et al., 2009). Chronic HRP treatment did not improve target organ damage in renovascular Goldblatt hypertensive rats with high renin, prorenin and PRA that lead to Ang-II dependent target organ damage rather HRP counteracts the beneficial effects of aliskiren (van Esch et al., 2011). Also, HRP had no effects on the activation of signal transduction mediated by prorenin-(P)RR interaction (Feldt et al., 2008a). On the other hand, very recently, (P)RR siRNA technique and prolonged use of HRP or valsartan showed inhibition of rapid phosphorylation in the serine residues of $(\mathrm{P}) \mathrm{RR}$ that ultimately suppressed inflammation in the kidneys (Huang et al., 2011). The concentration of HRP could not be measured in both blood and plasma of rats infused with either $0.1 \mathrm{or} 1 \mathrm{mg} / \mathrm{kg}$ HRP per day, which suggested rapid metabolism of the peptide in vivo and this interpretation was supported by the finding that HRP was metabolized with a half-life of 5 minutes in EDTA-plasma at $37^{\circ} \mathrm{C}$ (WikinsonBurka et al., 2011). Recycling of (P)RR between the cellular compartments and cell surface has been demonstrated earlier (Batenburge et al., 2007). Later, this annotation has been experimentally proved by the action of furin (Cousins et al., 2009) and ADAM19 (Yoshikawa et al., 2011), which till-to-date could be one of the most appropriate and acceptable explanation behind the useful execution of "decoy" as (P)RR blocker in some animal model or cell line while in other models, the "decoy" is not effective even at the same or sometimes higher concentration. 


\section{Conclusion and future direction}

A sensitive enzyme-linked immunosorbent assay has been established to detect the level of soluble (P)RR in the medium of cultured cells and also in cell lysates (Kazal et al., 2011). It is now very important to set up such easily pursuable and sensitive method for the detection of (P)RR in human plasma. It may facilitate to diagnose specific disease or to measure degree of organ damage or to predict the end-stage organ damage. Three dimensional structure of (pro)renin receptor has to be resolved to clear the ambiguity of decoy hypothesis, to find out the binding site(s) of prorenin, renin and the decoy peptide within the molecule. Furthermore, a well accepted (P)RR blocker is now the demand of time to reduce the effects of $(P) R R$ on end-stage organ damage. Thus, $(P) R R$, now-a-days, should be the novel target for developing new therapeutic approaches to ameliorate end-stage organ damage related disorders. However, considering the involvement of $(P) R R$ in organ development specially in eye and brain development, more extensive studies should be performed before designing a (P)RR blocker.

\section{References}

Achard V., Boullu-Ciocca S., Desbriere R., Nguyen G., \& Grino M. Renin receptor expression in human adipose tissue. Am. J. Physiol - Regu. Physiol., vol. 292, no. 1, (January 2007), pp. (R274-R282).

Advani A., Kelly DJ., Cox AJ, White KE., Advani SL., Thai K., Connelly KA., Yuen D., Trogadis J., Herzenberg AM., Kuliszewski MA., Leong-Poi H., \& Gilbert RE. The (Pro)renin receptor: site-specific and functional linkage to the vacuolar H+-ATPase in the kidney. Hypertension, vol. 54, no. 2, (August 2009), pp. (261-269).

Admiraal P.J., van Kesteren C.A., Danser A.H.J., Derkx F.H., Sluiter W., \& Schalekamp M.A.D.H. Uptake and proteolytic activation of prorenin by cultured human endothelial cells. J. Hypertens., vol. 17, no. 5, (May 1999), pp. (621-629).

Allen AM., Dosanjh JK., Erac M., Dassanayake S., Hannan RD., \& Thomas WG. Expression of constitutively active angiotensin receptors in the rostral ventrolateral medulla increases blood pressure. Hypertension, vol. 47, no.6, (June 2006), pp. (1054-1061).

Amsterdam A., Nissen RM., Sun Z., Swindell EC., Farrington S., \& Hopkins N. Identification of 315 genes essential for early zebra fish development. Proc. Natl. Acad. Sci. USA, vol. 10, no. 35, (August 2004), pp. (12792-12797).

Aronsson M., Almasan K., Fuxe K., Cintra A., Harfstrand A., Gustafsson JA., \& Ganten D. Evidence for the existence of angiotensinogen mRNA in magnocellular paraventricular hypothalamic neurons. Acta. Physiol. Scand., vol. 132, no. 4, (April 1988), pp. (585-586).

Azizi M., \& Menard J. Combined blockade of the renin-angiotensin systemwith angiotensinconverting enzyme inhibitors and angiotensinII type1 receptor antagonists. Circulation, vol. 109, no. 21, (June 2004), pp. (2492-2499).

Bader M. The second life of the (pro)renin receptor. Journal of Renin Angiotensin Aldosterone System, vol. 8, no. 4, (December 2007), pp. (205-208).

Batenburg W.W., Krop M., Garrelds I.M., de Vries R., de Bruin RJ., Burcklé CA., Müller DN., Bader M., Nguyen G., Danser AH. Prorenin is the endogenous agonist of the (pro)renin receptor. Binding kinetics of renin and prorenin in rat vascular smooth 
muscle cells overexpressing the human (pro)renin receptor. Journal of Hypertension, vol. 25, no. 12, (December 2007), pp. (2441-2453).

Bickerton RK., \& Buckley JP. Evidence for a central mechanism in angiotensin-induced hypertension. Proc. Soc. Exp. Biol. Med., vol 106, no. , (1961), pp. (834-837).

Biswas K.B., Nabi A.N., Arai Y., Nakagawa T., Ebihara A., Ichihara A., Inagami T., \& Suzuki F. Qualitative and quantitative analyses of (pro)renin receptor in the medium of cultured human umbilical vein endothelial cells. Hypertens. Res., vol. 34, no. 6, (June 2011), pp. (735-739).

Biswas KB, Nabi AH, Arai Y, Nakagawa T, Ebihara A, Suzuki F. Species specificity of prorenin binding to the (pro)renin receptor in vitro. Front. Biosci., vol. 2, (June 2010a), pp. (1234-1240).

Biswas K.B., Nabi A.H., Arai Y., Nakagawa T., Ebihara A., Ichihara A., Watanabe T., Inagami T., \& Suzuki F. Aliskiren binds to renin and prorenin bound to (pro)renin receptor in vitro. Hypertens. Res., vol. 33, no. 10, (October 2010b), pp. (1053-1059).

Boger J., Payne L.S., Perlow D.S., Lohr N.S., Poe M., Blaine E.H., Ulm E.H., Schorn T.W., LaMont B.I., Lin, T.Y. et al. Renin inhibitors. Syntheses of subnanomolar, competitive, transition-state analogue inhibitors containing a novel analogue of statine. J. Med. Chem., vol. 28, no. 12, (December 1985), pp. (1779-1790).

Bolis G., Fung AK., Greer J., Kleinert HD., Marcotte PA., Perun TJ., Plattner JJ. \& Stein H. Renin inhibitors: dipeptide analogues of angiotensinogen incorporating transitionstate, nonpeptidic replacements at the scissile bond. J .Med. Chem., vol. 30, no. 10, (October 1987), pp. (1729-1237).

Buechling T., Bartscherer K., Ohkawara B., Chaudhary V., Spirohn K., Niehrs C., \& Boutros M. Wnt/Frizzled signaling requires dPRR, the Drosophila homolog of the prorenin receptor. Curr. Biol., vol. 20, no. 14, (July 2010), pp. (1263-1268).

Brecher A.S., Shier D.N., Dene H., Wang S.M., Rapp J.P., Franco S.R., \& Mulrow P.J. Regulation of adrenal renin messenger ribonucleic acid by dietary sodium chloride. Endocrinology, vol. 124, no. 6, (June 1989), pp. (2907-2913).

Burckle C.A., Danser A.H.J., Muller D.N., Garrelds I.M., Gasc J.M., Popova E., Plehm R., Peters J., Bader M., \& Nguyen G. Elevated blood pressure and heart rate in human renin receptor transgenic rats. Hypertension, vol. 47, no. 6, (March 2006), pp. (552556).

Burckle, C., \& Bader M. Prorenin and its ancient receptor. Hypertension, vol. 48, no. 4, (2006), pp. (549-551).

Campbell D.J. Critical review of prorenin and (pro)renin receptor research. Hypertension, vol. 51, no. 5, (March, 2008), pp. (1259-1264).

Campbell D.J., Kladis A., \& Duncan A.M. Nephrectomy, converting enzyme inhibition and angiotensin peptides. Hypertension. Vol. 22, no. 4, (October, 1993), pp. (513-522).

Campbell D.J., \& Valentijn A.J. Identification of vascular renin-binding proteins by chemical cross-linking: inhibition of binding of renin by renin inhibitors. J. Hypertens., vol. 12, no. 8, (August 1994), pp. (879-890).

Cohen S., Taylor J.M., Murakami K., Michelakis A.M., \& Inagami T. Isolation and characterization of renin-like enzymes from mouse submaxillary glands. Biochemistry, vol. 11, no. 23, (November 1972); pp. (4286-4293). 
Cooper J.R., Bloom F.E., Roth R.H. (1996). Biochemical Basis of Neuropharmacology. Oxford Univ. Press, Oxford, UK.

Cousin C., Bracquart D., Contrepas A., Corvol P., Muller L., \& Nguyen G. Soluble form of the (pro)renin receptor generated by intracellular cleavage by furin is secreted in plasma. Hypertension, vol. 53, no. 6, (June 2009), pp. (1077-1082).

Contrepas A., Walker J., Koulakoff A., Franek K.J., Qadri F., Giaume C., Corvol P., Schwartz C.E., \& Nguyen G.A. Role of the (pro)renin receptor in neuronal cell differentiation. Am. J. Physiol. Regul. Integr. Comp. Physiol., vol. 297, no. 2, (August 2009), pp. (R250R257).

Dai C.., Stolz D.B., Kiss L.P., Monga S.P., Holzman L.B., \& Liu Y. Wntbeta-catenin signaling promotes podocyte dysfunction and albuminuria. J. Am. Soc. Nephrol., vol. 20, no. 9, (September 2009), pp. (1997-2008).

Danser A.H.J., van Kats J.P., Admiraal P.J.J., Derkx F.H.M., Lamers J.M.J., Verdouw P.D., Saxena P.R., \& Schalekamp M.A.D.H. Cardiac renin and angiotensins: uptake from plasma versus in situ synthesis. Hypertension. vol. 24, no. 1, (July 1994), pp. (37-48).

Danser A.H.J., Koning M.M.G., Admiraal P.J.J., Sassen L.M., Derkx F.H., Verdouw P.D., \& Schalekamp M.A. Production of angiotensins I and II at tissue sites in the intact pig. Am. J. Physiol., vol. 263, no. 2, (August 1992), pp. (H429-H437).

Derkx F.H.M., Tan-Tjiong H.L., Man in 't Veld A.J., Schalekamp M.P., \& Schalekamp M.A.D.H. Activation of inactive plasma renin by plasma and tissue kallikreins. Clin. Sci. (Lond)., vol. 57, no. 4, (October 1979), pp. (351-357).

Derkx F.H.M., Tan-Tjiong L., Wenting G.J., Boomsma F., Man in 't Veld A.J and Schalekamp M.A.D.H. Asynchronous changes in prorenin and renin secretion after captopril in patients with renal artery stenosis. Hypertension., vol. 5, no. 2, (March-April 1983), pp. (244-256).

Derkx F.H., Alberda A.T., de Jong F.H., Zeilmaker F.H., Makovitz J.W., Schalekamp \& M.A. Source of plasma prorenin in early and late pregnancy: observations in a patient with primary ovarian failure. J. Clin. Endocrinol. Metab., vol. 65, no. 2, (August 1987a), pp. (349-354).

Derkx F.H.M., Schalekamp M.P., \& Schalekamp M.A.D.H. Two-step prorenin-renin conversion. Isolation of an intermediary form of activated prorenin. J. Biol. Chem., vol. 262, no. 6, (February 1987b), pp. (2472-2477).

Derkx F.H.M., Deinum J., Lipovski M., Verhaar M., Fischli W., \& Schalekamp M.A.D.H. Nonproteolytic "activation" of prorenin by active site-directed renin inhibitors as demonstrated by renin-specific monoclonal antibody. J. Biol. Chem., vol. 267, no. 32, (November 1992), pp. (22837-22842).

Deschepper C.F., Mellon S.H., Cumin F., Baxter J.D., \& Ganong W.F. Analysis by immunocytochemistry and in situ hybridization of renin and its mRNA in kidney, testis, adrenal, and pituitary of the rat. Proc. Natl. Acad. Sci. U.S.A., vol. 83, no. 19, (October 1986), pp. (7552-7556).

Do Y.S., Sherrod A., Lobo R.A., Paulson R.J., Shinagawa T., Chen S.W., Kjos S., \& Hsueh W.A. Human ovarian theca cells are a source of renin. Proc. Natl. Acad. Sci. U. S. A., vol. 85, no. 6, (1March 988), pp. (1957-1961).

de Lannoy L.M., Danser A.H.J., van Kats J.P., Schoemaker R.G., Saxena P.R., \& Schalekamp M.A.D.H. Renin-angiotensin system components in the interstitial fluid of the 
isolated perfused rat heart. Local production of angiotensin I. Hypertension, vol. 29, no. 6, (June 1997), pp. (1240-1251).

de Lannoy L.M., Danser A.H.J., Bouhuizen A.M.B., Saxena P.R., \& Schalekamp M.A.D.H. Localization and production of angiotensin II in the isolated perfused rat heart. Hypertension, vol. 31, no. 5, (May 1998), pp. (1111-1117).

De Mello W.C. Influence of intracellular renin on heart cell communication. Hypertension, vol. 25, no. 6, (June 1995), pp. (1172-1177).

Deschepper C.F., Bouhnik J., \& Ganong W.F. Colocalization of angiotensinogen and glial fibrillary acidic protein in astrocytes in rat brain. Brain. Res., vol. 374, no. 1, (May 1986), pp. (195-198).

Dhanaraj V., Dealwis C.G., Frazao C., Badasso M., Sibanda B.L., Tickle I.J., Cooper J.B., Driessen H.P., Newman M., Aguilar C. X-ray analyses of peptide-inhibitor complexes define the structural basis of specificity for human and mouse renins. Nature., vol. 357, no. 6378, (June, 1992), pp. (466-472).

Deinum J., Rønn B., Mathiesen E., Derkx F.H., Hop W.C., Schalekamp M.A. Increase in serum prorenin precedes onset of microalbuminuria in patients with insulindependent diabetes mellitus.Diabetologia, vol. 42, no. 8, (August 1999), pp. (10061010).

Doi Y., Franco S.R. \& Mulrow P.J. Evidence for an extra renal source of inactive renin in rats. Hypertension, vol. 6, no. 5, (September 1984) pp. (6627-6632).

Dostal D.E., Rothblum K.N., Chernin M.I., Cooper G.R., \& Baker K.M. Intracardiac detection of angiotensinogen and renin: a localized renin - angiotensin system in neonatal rat heart. Am. J. Physiol., vol. 263, no. 4 Pt 1, (October 1992), pp. (C838-C850).

Du D., Kato T., Nabi A.H.M.N., Suzuki F., \& Park E.Y. Expression of functional human (pro)renin receptor in silkworm (Bombyx mori) larvae using BmMNPV bacmid. Biotechnology and Applied Biochemistry, vol. 49, no. 3, (March 2008), pp. (195-202).

Dzau V.J., Ellison K.E., Brody T., Ingelfinger J., \& Pratt R.E. A comparative study of the distributions of renin and angiotensinogen messenger ribonucleic acids in rat and mouse tissues. Endocrinology, vol. 120, no. 6, (June 1987), pp. (2334-2338).

Dzau V.J., Ingelfinger J., Pratt R.E., \& Ellison K.E. Identification of renin and angiotensinogen messenger RNA sequences in mouse and rat brains. Hypertension, vol. 8, no. 6, (June 1986), pp. (544-548).

Dzau V.J., Slater E.E., \& Haber, E. Complete purification of human renin. Biochemistry, vol. 18, no. 23, (November 1979), pp. (524-528).

Epstein A.N., Fitzsimons J.T., \& Rolls B.J. Drinking induced by injection of angiotensin into the rain of the rat. J. Physiol., vol. 210, no. 2, (September 1970), pp. (457-474).

Feldt S. Maschke U. Dechend R., Luft F.C. \& Muller D.N. The putative (pro)renin receptor blocker HRP fails to prevent (pro)renin signaling. J. Am. Soc. Nephrol., vol. 19, no. 4, (April 2008a), pp. (743-748).

Feldt S. Batenburg W.W., Mazak I., Maschke U., Wellner M., Kvakan H., Dechend R., Fiebeler A., Burckle C., Contrepas A., Danser A.H.J., Bader M., Nguyen G., Luft F.C., \& Muller D.N. Prorenin and renin-induced extracellular signal-regulated kinase $1 / 2$ activation in monocytes is not blocked by aliskiren or the handle-region peptide. Hypertension, vol. 51, no. 3, (March 2008b), pp. (682-688). 
Figueired, A.F.S., Takii Y., Tsuji, H., Kato K. \& Inagami T. Rat kidney renin and chatepsin D: purification and comparison of properties. Biochemistry, vol. 22, no. 24, (November 1985), pp. (5476-5481).

K.E. Finberg, G.A. Wagner, M.A. Baileyetal. The B1-subunit of the $\mathrm{H}^{+}$ATPase is required for maximal urinary acidification. Proc. Natl. Acad. Sci. USA, vol.102, no.38, (September 2005), pp. (13616-13621).

Fischer-Ferraro C., Nahmod V.E., Goldstein D.J., \& Finkielman S. Angiotensin and renin in rat and dog brain. J. Exp. Med., vol. 133, no. 2, (February 1971), pp. (353-361).

Ganten D, Minnich JL, Granger P, Hayduk K, Brecht HM, Barbeau A, Boucher R, Genest J. Angiotensin-forming enzyme in brain tissue. Science, vol. 173, no. 991, (July 1971), pp. (64-65).

Ganten D., Ganten U., Kubo S., Granger P., Nowaczynski W., Boucher R., \& Genest J. Influence of sodium, potassium and pituitary hormones on iso-renin in rat adrenal glands. Am. J. Physiol., vol. 227, no. 1, (July 1974), pp. (224-229).

Ganten D., Hutchinson J.S., Schelling P., Ganten U., \& Fischer H. The iso-renin angiotensin systems in extra-renal tissue. Clin. Exp. Pharmacol. Physiol., vol. 3, no. 2, (MarchApril 1976), pp. (102-126).

Glorioso N., Atlas S.A., Laragh J.H., Jewelewicz R., \& Sealey J.E. Prorenin in high concentrations in human ovarian follicular fluid. Science, vol. 233, no. 4771, (September 1986), pp. (1422-1424).

Goto M., Mukoyama M., Suga S.I., Matsumoto T., Nakagawa M., Ishibashi R., Kasahara M., Sugawara A., Tanaka I., \& Nakao K. Growth-dependent induction of angiotensin II type 2 receptor in rat mesangial cells. Hypertension, vol. 30, no. 3, (September 1997), pp. (358-362).

Gross V., Schunck W.H., Honeck H., Milia A.F., Kärgel E., Walther T., Bader M., Inagami T., Schneider W., \& Luft F.C. Inhibition of pressure natriuresis in mice lacking the AT receptor. Kidney Int., vol. 57, no. 1, (January 2000), pp. (191-202).

He W., Dai C., Li Y., Zeng G., Monga S.P., Liu Y. Wntbeta-catenin signaling promotes renal interstitial fibrosis. J. Am. Soc. Nephrol., vol. 20, no. 4, (April 2009), pp. (765-776).

Hermle T., Saltukoglu D., Grünewald J., Walz G., \& Simons M. Regulation of Frizzleddependent planar polarity signaling by a V-ATPase subunit. Curr. Biol., vol 20, no. 14, (July 2010), pp, (1269-1276).

Hirose T., Hashimoto M., Totsune K., Metoki H., Hara A., Satoh M., Kikuya M., Ohkubo T., Asayama K., Kondo T., Kamide K., Katsuya T., Ogihara T., Izumi S., Rakugi H., Takahashi K., \& Imai Y. Association of (pro)renin receptor gene polymorphisms with lacunar infarction and left ventricular hypertrophy in Japanese women: the Ohasama study. Hypertens. Res., vol. 34, no. 4, (April 2011), pp. (530-535).

Hirose T., Mori N., Totsune K., Morimoto R., Maejima T., Kawamura T., Metoki H., Asayama K., Kikuya M., Ohkubo T., Kohzuki M., Takahashi K., \& Imai Y. Gene expression of (pro)renin receptor is upregulated in hearts and kidneys of rats with congestive heart failure. Peptides, vol. 30, no. 12, (December 2009), pp. (2316-2322).

Hirose S., Ohsawa T., Inagami T., \& Murakami K., Brain renin from bovine anterior pituitary: isolation and properties. J. Biol. Chem., vol. 257, no. 11, (June 1982), pp. (6316-6321). 
Hirose S., Yokosawa H., \& Inagami T. Immunochemical identification of renin in rat brain and distinction from acid protease. Nature, vol. 274, no. 5669, (July 1978), pp. (392393).

Ho M.M., \& Vinson G.P. Transcription of (pro)renin mRNA in the rat adrenal cortex, and the effects of ACTH treatment and a low sodium diet. Journal of Endocrinology, vol. 157, no. 2, (May 1998), pp. (217-223).

Hokimoto S., Yasue H., Fujimoto K., Yamamoto H., Nakao K., Kaikita K., Sakata R., \& Miyamoto E. Expression of angiotensin-converting enzyme in remaining viable myocytes of human ventricles after myocardial infarction. Circulation, vol. 94, no. 7, (October 1996), pp. (1513-1518).

Hollenberg N.K., Fisher N.D., \& Price, D.A. Pathways for angiotensin II generation in intact human tissue: evidence from comparative pharmacological interruption of the renin system. Hypertension, vol. 32, no. 3, (September 1998), pp. (387-392).

Holm I., Ollo R., Panthier J.J., \& Rougeon F. Evolution of aspartyl proteases by gene duplication: the mouse renin gene is organized in two homologous clusters of four exons. EMBO J., vol. 3, no. 3, (March 1984), pp. (557-562).

Huang Y., Wongamorntham S., Kasting J., McQuillan D., Owens R.T., Yu L., Noble N.A., \& Border W. Renin increases mesangial cell transforming growth factor-beta1 and matrix proteins through receptormediated, angiotensin II-independent mechanisms. Kidney Int., vol. 69, no. 1, (January 2006), pp. (105-113).

Huang J., Matavelli L.C., \& Siragy M. Renal (pro)renin receptor contribute to the development of diabetic kidney disease through transforming growth factor- $\beta 1$ and connective tissue growth factor signaling cascades. Clinical and Experimental Pharmacology and Physiology, vol. 38, no. 4, (April 2011), pp. (215-221).

Huang J., \& Siragy H,M. Regulation of (pro)renin receptor expression by glucose-induced mitogen-activated protein kinase, nuclear factor-kappaB, and activator protein-1 signaling pathways. Endocrinology, vol. 151, no. 7, (July 2010), pp. (3317-3325).

Hui K.Y., Carlson W.D., Bernatowicz M.S., \& Haber, E. Analysis of structure-activity relationships in renin substrate analogue inhibitory peptides. J. Med. Chem., vol. 30, no. 8, (August 1987), pp. (1287-1295).

Ichihara A., Hayashi M., Kaneshiro Y., Suzuki F., Nakagawa T., Tada Y., Koura Y., Nishiyama A., Okada H., Uddin M.N., Nabi A.H.M.N., Ishida Y., Inagami T., \& Saruta $\mathrm{T}$. Inhibition of diabetic nephropathy by a decoy peptide corresponding to the "handle" region for non-proteolytic activation of prorenin. J. Clin. Invest., vol. 114, no. 8, (October 2004), pp. (1128-1135).

Ichihara A., Kaneshiro Y., \& Takemitsu T. Contribution of nonproteolytically activated prorenin in glomeruli to hypertensive renal damage. J. Am. Soc. Nephrol., vol. 17, no. 9, (September 2006a), pp. (2495-2503).

Ichihara A., Kaneshiro Y., Takemitsu T., Sakoda M., Suzuki F., Nakagawa T., Nishiyama A., Inagami T., \& Hayashi M. Non proteolytic activation of prorenin contributes to development of cardiac fibrosis in genetic hypertension. Hypertension, vol. 47, no. 5, (May 2006b), pp. (894-900).

Ichihara A., Suzuki F., Nakagawa T., Kaneshiro Y., Takemitsu T., Sakoda M., Nabi A.H.M.N., Nishiyama A., Sugaya T., Hayashi M., \& Inagami T. Prorenin receptor blockade inhibits development of glomerulosclerosis in diabetic angiotensin II type 
1a receptor deficient mice. J. Am. Soc. Nephrol., vol. 17, no. 7, (July 2006c), pp. (19501961).

Imagawa M., Chiu R., \& Karin M. Transcription factor AP-2 mediates induction by two different signal-transduction pathways: protein kinase C and cAMP. Cell, vol. 51, no. 2, (October 1987), pp. (251-260).

Inagami T. \& Murakami K. Prorenin. Biomed. Res., vol. 1, no. , (1980), pp. (456-475).

Inagami T. \& Murakami K. Pure renin: isolation from hog kidney and characterization. J. Biol. Chem., vol. 252, no. 9, (May 1977), pp. (2978-2983).

Inoue H., Noumi, T. Nagata M., Murakami H., \& Kanazawa H. Targeted disruption of the gene encoding the proteolipid subunit of mouse vacuolar H-ATPase leads to early embryonic lethality. Biochimica et Biophysica Acta.,vol. 1413, no. 3, (November 1999), pp. (130-138).

Ito M., Oliverio M.I., Mannon P.J., Best C.F., Maeda N., Smithies O., \& Coffman T.M. Regulation of blood pressure by the type 1A angiotensin II receptor gene. Proc. Natl. Acad. Sci. USA, vol. 92, no. 8, (April 1995), pp. (3521-3525).

Itskovitz J., \& Sealey J.E. Ovarian prorenin-renin-angiotensin system. Obstet. Gynecol. Surv., vol. 42, no. 9, (September 1987), pp. (545-551).

Jones C.A., Petrovic N., Novak E.K., Swank R.T., Sigmund C.D. \& Gross K.W. Biosynthesis of renin in mouse kidney tumor As4.1 cells. Eur. J. Biochem., vol. 243, no. 1-2, (January 1997), pp. (181-190).

Jutras I., \& Reudelhuber T.L. Prorenin processing by cathepsin B in vitro and in transfected cells. FEBS Lett., vol. 443, no. 1, (January 1999), pp. (48-52).

Kaneshiro Y., Ichihara A., Sakoda M., Takemitsu T., Nabi A.H.M.N., Uddin M.N., Nakagawa T., Nishiyama A., Suzuki F., Inagami T., \& Itoh H. Slowly progressive, angiotensin II-independent glomerulosclerosis in human-renin/prorenin-receptortransgenic rats. J. Am. Soc. Nephrol., vol. 18, no. 6, (June 2007), pp. (1789-1795).

Julie K.J., Toma I., Sipos A., Elliott J., Sarah M., Vargas L., \& Peti-Peterdi J. The collecting duct is the major source of $\mathrm{p}$ rorenin in diabetes. Hypertension, vol 51, no. 6, (June 2008), pp. (1597-1604).

Kato T., Du D., Suzuki F., \& Park E.Y. Localization of human (pro)renin receptor lacking the transmembrane domain on budded baculovirus of Autographa californica multiple nucleopolyhedrovirus. Appl. Microbiol. Biotechnol., vol. 82, no. 3, (March, 2009), pp. (431-437).

Kato T., Kageshima A., Suzuki F., \& Park E.Y. Expression and purification of human (pro)renin receptor in insect cells using baculovirus expression system. Protein Expr Purif., vol. 58, no. 2, (April, 2008), pp. (242-248).

Karet F.E., Finberg K.E., \& Nelson R.D., Nayir A., Mocan H., Sanjad S.A., Rodriguez-Soriano J., Santos F., Cremers C.W., Di Pietro A., Hoffbrand B.I., Winiarski J., Bakkaloglu A., Ozen S., Dusunsel R., Goodyer P., Hulton S.A., Wu D.K., Skvorak A.B., Morton C.C., Cunningham M.J., Jha V., Lifton R.P.. Mutations in the gene encoding B1 subunit of H+-ATPase cause renal tubular acidosis with sensor in neural deafness. Nature Genetics, vol. 21, no. 1, (January 1999), pp. (84-90).

Kim W.S., Nakayama K., Nakagawa T., Kawamura Y., Haraguchi K., \& Murakami K. Mouse submandibular gland prorenin-converting enzyme is a member of glandular kallikrein family. J. Biol. Chem., vol. 266, no. 29, (October 1991), pp. (19283-19287). 
Kobori H., Ozawa Y., Suzakietal Y., Prieto-Carrasquero M.C., Nishiyama A., Shoji, T., Cohen E.P., \& Navar L.G. Young scholars award lecture. Intratubular angiotensinogen in hypertension and kidney diseases. Am. J. Hypertens., vol. 19, no. 5, (May 2006), pp. (541-550).

Kikkawa Y., Yamanaka N., Tada J., Kanamori N., Tsumura K., \& Hosoi K. Prorenin processing and restricted endoproteolysis by mouse tissue kallikrein family enzymes (MK1, MK9, MK13, and MK22). Biochim. Biophys. Acta Protein Struc. Mol. Enzymol., vol. 1382, no. 1, (January 1998), pp. (55-64).

Kinouchi K., Ichihara A., Sano M., Sun-Wada G.H., Wada Y., Kurauchi-Mito A., Bokuda K., Narita T., Oshima Y., Sakoda M., Tamai Y., Sato H., Fukuda K., \& Itoh H. The (pro)renin receptor/ATP6AP2 is essential for vacuolar $\mathrm{H}^{+}$-ATPase assembly in murine cardiomyocytes. Circ. Res., vol. 107, no. 1, (July 2010), pp. (30-34).

Leckie B.J., Bottrill A.R. A specific binding site for the prorenin propart peptide Arg10-Arg20 does not occur on human endothelial cells. J Renin Angiotensin Aldosterone Syst., vol. 12, no. 1, (May 2011), pp. (36-41).

Lenz T., James G.D., Laragh J.H., \& Sealey J.E. Prorenin secretion from human placenta perfused in vitro. American Journal of Physiology, Endocrinology and Metabolism. Am. J. Physiol., vol. 260 no. 6, (June 1991), pp. (E876-E882).

Liang F., \& Gardner D.G. Autocrine/paracrine determinants of strain-activated brain natriuretic peptide gene expression in cultured cardiac myocytes. J. Biol. Chem., vol. 273, no. 23, (1998), pp. (14612-14619).

Li Y.P., Chen W., Liang Y., Li E., \& Stashenko P. ATP6i-deficient mice exhibit severe osteopetrosis due to loss of osteoclast-mediated extracellular acidification. Nature Genetics., vol. 23, no. 4, (December 1999), pp. (447-451).

Logan C.Y., \& Nusse R. The Wnt signaling pathway in development and disease. Annu. Rev. Cell Dev. Biol., vol. 20, (2004), pp. (781-810).

Ludwig J., Kerscher S., Brandt U., Pfeiffer K., Getlawi F., Apps D.K., \& Schägger H. Identification and characterization of a novel 9.2-kDa membrane sector-associated protein of vacuolar proton-ATPase from chromaffin granules. J. Biol. Chem., vol. 278, no. 18, (May 1998), pp. (10939-10947).

Maibaum J., \& Feldman D.L. Renin inhibitors as novel treatments for cardiovascular disease. Expert. Opin. Ther. Patents, vol. 13, (2003), pp. (589-603).

Manne K., \& Danser A.H.J. Circulating versus tissue renin-angiotensin system: On the origin of (pro)renin. Curr. Hypertense. Rep., vol. 10, no., 2, (April 2008), pp. (112-118).

Matavelli L.C., Huang J., \& Siragy H.M. (Pro)renin receptor contributes to diabetic nephropathy by enhancing renal inflammation. Clin. Exp. Pharmacol. Physiol., vol. 37, no., 3, (March 2010), pp. (277-282).

Miura G.I., Froelick G.J., Marsh D.J., Stark K.L., \& Palmiter R.D. The d subunit of the vacuolar ATPase (Atp6d) is essential for embryonic development. Transgenic Research., vol. 12, no. 1, (February 2003), pp. (131-133).

Matoba T., Murakami K. \& Inagami, T. Rat renin: purification and characterization. Biochim. Biophys. Acta., vol. 526, no. 2, (October 1978), pp. (560-571).

Ménard J, Boger R.S., Moyse D.M., Guyene T.T., Glassman H.N., \& Kleinert H.D. Dosedependent effects of the renin inhibitor zankiren HCI after a single oral dose in 
mildly sodium-depleted normotensive subjects. Circulation, vol. 91, no. 2, (January 1995), pp. (330-338).

Mercure C., Prescott G., Lacombe M.J., Silversides D.W., \& Reudelhuber T.L. Chronic increases in circulating prorenin are not associated with renal or cardiac pathologies. Hypertension., vol. 53, no. 6, (June 2009), pp. (1062-1069).

Mooser V., Nussberger J., Jullierat L. Reactive hyperreninemia is a major determinant of plasma angiotensin II during ACE inhibition. J. Cardiovasc. Pharmacol., vol. 15, no. 2, (February, 1990), pp. (276-282).

Murakami K., \& Inagami T. Isolation of pure and stable renin from hog kidney. Biochem. Biophys. Res. Commun., vol. 62, no. 3, (February, 1975), pp. (757-763).

Muller D.N., Klanke B., Feldt S., Cordasic N., Hartner A., Schmieder R.E., Luft F.C., \& Hilgers K.F. (Pro)renin receptor peptide inhibitor "handle-region" peptide does not affect hypertensive nephrosclerosis in goldblatt rats. Hypertension, vol. 51, no. 3, (March 2008), pp. (676-681).

Nabi A.H.M.N., Biswas K.B., Nakagawa T., Ichihara A., Inagami T., \& Suzuki F. 'Decoy peptide' region (RIFLKRMPSI) of prorenin prosegment plays a crucial role in prorenin binding to the (pro)renin receptor. Int. J. Mol. Med. Vol. 24, no. 1, (July 2009a), pp. (83-89).

Nabi A.H.M.N., Biswas K.B., Nakagawa T., Ichihara A., Inagami T., \& Suzuki F. Prorenin has high affinity multiple binding sites for (pro)renin receptor. Biochim. Biophys. Acta., vol. 1794, no. 12, (December 2009b), pp. 1838-1847.

Nabi A.N., Biswas K.B., Arai Y., Nakagawa T., Ebihara ., Islam L.N., Suzuki F. (Pro)renin receptor and prorenin: their plausible sites of interaction. Front Biosci., January 2012, In press.

Nabi A.H.M.N., Kageshima A., Uddin M.N., Nakagawa T., Park E.Y., \& Suzuki F. Binding properties of rat prorenin and renin to the recombinant rat renin/prorenin receptor prepared by a baculovirus expression system. Int. J. Mol. Med., vol. 18, no. 3, (2006), pp. (483-488).

Nabi A.H.M.N., Biswas K.B., Arai Y., Uddin M.N., Nakagawa T., Ebihara A., Ichihara A., Inagami T., \& Suzuki F. Functional characterization of the decoy peptide, R10PIFLKRMPSI19P. Front. Biosci., vol. 2, (June, 2010), pp. (1211-1217).

Naruse, K.; Takii, Y.; Inagam, T., Immunohistochemical localization of luteinizing hormone producing cells of rat pituitary. Proc. Nat. Acad. Sci., U.S.A. vol. 78, no. , (1981), pp. (7579-7583).

Naruse M., \& Inagami T., Markedly elevated specific renin level in the adrenal in genetically hypertensive rats. Proc. Natl. Acad. Sci. U.S.A.78, (1982) 3295-3299.

Nelson N., Perzov N., Cohen A., Hagai K., Padler V., Nelson H. The cellular biology of proton-motive force generation by V-ATPases. J. Exp. Biol., vol. 203, no. 1, (2000), pp. (89-95).

Neri Serneri G.G., Boddi M., Coppo M., Chechi T., Zarone N., Moira M., Poggesi L., Margheri M., Simonetti I. Evidence for the existence of a functional cardiac reninangiotensin system in humans. Circulation, vol. 94, no. 8, (October 1996), pp. (18861893). 
Nguyen G. Increased cyclooxygenase-2, hyperfiltration, glomerulosclerosis, and diabetic nephropathy: put the blame on the (pro)renin receptor? Kidney International, vol. 70, no. 4, (August 2006), pp. (618-620).

Nguyen G., Delarue F., Berrou J., Rondeau E., Sraer J.D. Specific receptor binding of renin on human mesangial cells in culture increases plasminogen activator inhibitor-1 antigen. Kidney Int., vol. 50, no. 6, (1996), pp. (1897-1903).

Nguyen G., Bouzhir L., Delarue F., Rondeau E., \& Sraer J.D. Evidence of a renin receptor on human mesangial cells: effects on PAI1 and cGMP. Nephrologie, vol. 19, no. 7, (1998), pp. (411-416).

Nguyen G., Delarue F., Burckle C., Bouzhir L., Giller T. \& Sraer J.D. Pivotal role of the renin/prorenin receptor in angiotensin II production and cellular responses to renin. J. Clin. Invest., vol. 109, no. 11, (June 2002), pp. (1417-1427).

Nurun NA., Uddin MN., Nakagawa T., Iwata H., Ichihara A., Inagami T., \& Suzuki F. Role of "handle" region of prorenin prosegment in the non-proteolytic activation of prorenin by binding to membrane anchored (pro)renin receptor. Front. Biosci., vol. 12, (September 2007), pp. (4810-4817).

Nussberger J., Wuerzner G., Jensen C., \& Brunner, H.R. Angiotensin II suppression in humans by the orally active renin inhibitor aliskiren (SPP100). Comparison with enalapril. Hypertension, vol. 39, no. 1, (January 2002), pp. (e1-e8).

Oparil S., \& Haber E. The renin-angiotensin system (first of two parts). N. Engl. J. Med., vol. 291, no. 8, (August 1974a), pp. (389-401).

Oparil S., \& Haber E. The renin-angiotensin system (second of two parts). N. Engl. J. Med., vol. 291, no. 9, (August 1974b), pp. (446-457).

Ott C., Schneider M., Delles C., Schlaich M.P., Hilgers K.F., \& Schmieder R.E. Association of (pro)renin receptor gene polymorphism with blood pressure in Caucasian men. Pharmacogenetics and Genomics, vol. 21, no. 6, (June 2011), pp. (347-349).

Pandey K.N., Melner N. M., Paramentier M., \& Inagami T. Demonstration of renin activity in purified rat Leydig cells: evidence for the existence of endogenous inactive (latent) form of enzyme. Endocrinol., vol. 115, no. 5, (November 1984), pp. (175317590).

Paul P., Wagner D., Metzger R., Ganten D., Lang R.E., Suzuki F., Murakami K., Burbach J.H.P., \& Ludwig G. Quantification of renin mRNA in various mouse tissues by a novel solution hybridization assay. J. Hypertens., vol. 6, no. 3, (March 1988), pp. (247-252).

Pickens P.T., Bumpus F.M., Lloyd AmM., Smeby R.R., \& Page I.H. Measurements of renin activity in human plasma. Circ. Res., vol. 17, no. 5, (November 1965), pp. (438-448).

Pitarresi T.M., Rubattu S., Heinrikson R. \& Sealey J.E. Reversible cryoactivation of recombinant human prorenin. J. Biol. Chem., vol. 267, no. 17, (June 1992), pp. (11753-11759).

Prescott G., Silversides D.W., \& Reudelhuber T.L. Tissue activity of circulating prorenin. Am. J. Hypertens., vol. 15, no. 3, (March 2002), pp. (280-285).

Prieto-Carrasquero M.C., Harrison-Bernard L.M., Kobori H., Ozawa Y., Hering-Smith K.S., Hamm L.L., Navar L.G. Enhancement of collecting duct renin in angiotensin IIdependent hypertensive rats. Hypertension., vol. 44, no. 4, (August 2004), pp. (223229). 
Rohrwasser A., Morgan T., Dillon H.F., Zhao L., Callaway C.W., Hillas E., Zhang S., Cheng T., Inagami T., Ward K., Terreros D.A., \& Lalouel J.M. Elements of a paracrine tubular renin angiotensin system along the entire nephron. Hypertension., vol. 34, no. 6, (December 1999), pp. (1265-1274).

Rongen G.A., Lenders J.W.M., Smits P. \& Thien T. Clinical pharmacy okinetics and efficacy of renin inhibitors. Clin. Pharmacokinet., vol. 29, no. 1, (July 1995), pp. (6-14).

Ruzicka M., Yuan B., \& Leenen F.H.M. Effects of enalapril versus losartan on regression of volume overload-induced cardiac hypertrophy in rats. Circulation., vol. 90, no. 1, (July 1994), pp. (484-491).

Sadoshima J., Xu Y., Slayter H.S., \& Izumo S. Autocrine release of angiotensin II mediates stretch-induced hypertrophy of cardiac myocytes in vitro. Cell, vol. 95, no. 5, (December 1993), pp. (977-984).

Saris J.J., Derkx F.H.M., de Bruin R.J.A., Dekkers D.H., Lamers J.M., Saxena P.M., Schalekamp M.A., \& Danser A.H.J. High-affinity prorenin binding to cardiac man6-P/IGF-II receptors precedes proteolytic activation to renin. Am. J. Physiol.-Heart Circ. Physiol., vol. 280, no. 4, (April 2001), pp. (H1706-H1715).

Saris J.J., 't Hoen P.A., Garrelds I.M., Dekkers D.H., den Dunnen J.T., Lamers J.M., Danser A.H.J. Prorenin induces intracellular signalling in cardiomyocytes independently of angiotensin II. Hypertension, vol. 48, no. 4, (October 2006), pp. (564-571).

Satofuka S., Ichihara A., Nagai N., Yamashiro K., Koto T., Shinoda H., Noda K., Ozawa Y., Inoue M., Tsubota K., Suzuki F., Oike Y., \& Ishida S. Suppression of ocular inflammation in endotoxin-induced uveitis by inhibiting nonproteolytic activation of prorenin. Invest. Ophth. Vis. Sci., vol. 47, no. 6, (June 2006), pp. (2686-2692).

Satofuka S., Ichihara A., Nagai N., Koto T., Shinoda H., Noda K., Ozawa Y., Inoue M., Tsubota K., Itoh H., Oike Y., \& Ishida S. Role of nonproteolytically activated prorenin in pathologic, but not physiologic, retinal neovascularization. Invest. Ophth. Vis. Sci., vol. 48, no. 1, (January 2007), pp. (422-429).

Satofuka S., Ichihara A., Nagai N., Noda K., Ozawa Y., Fukamizu A., Tsubota K., Itoh H., Oike Y., \& Ishida S. (Pro)renin receptor promotes choroidal neovascularization by activating its signal transduction and tissue renin-angiotensin system. Am. J. Pathol., vol. 173, no. 6, (December 2008), pp. (1911-1918).

Satofuka S., Ichihara A., Nagai N., Noda K., Ozawa Y., Fukamizu A., Tsubota K., Itoh H., Oike, Y., \& Ishida S. (Pro)renin receptor-mediated signal transduction and tissue renin-angiotensin system contribute to diabetes-induced retinal inflammation. Diabetes, vol. 58, no. 7, (July 2009), pp. (1625-1633).

Schefe J.H., Menk, M., Reinemund J., Effertz K., Hobbs R.M., Pandolfi P.P., Ruiz P., Unger T., Funke-Kaiser H. A novel signal transduction cascade involving direct physical interaction of the renin/prorenin receptor with the transcription factor promyelocytic zinc finger protein. Circ. Res., vol. 99, no. 12, (December 2006), pp. (1355-1366).

Schieffer B., Wirger A., Meybrunn M., Seitz S., Holtz J., Riede U.N., \& Drexler H. Comparative effects of chronic angiotensin-converting enzyme inhibition and angiotensin II type 1 receptor blockade on cardiac remodeling after myocardial infarction in the rat. Circulation, vol. 89, no. 5, (May 1994), pp. (2273-2282). 
Schnermann J., \& Briggs J.P. Function of the juxtaglomerular apparatus: control of glomerular hemodynamics and renin secretion. In: Alpern RJ, Hebert SC, editors. The Kidney Physiology and Pathophysiology. Burlington-San Diego-London: Elsevier Academic Press; 2008. pp. 589-626.

Schweda F., Friis U., Wagner C., Skott O., \& Kurtz A. Renin release. Physiology (Bethesda), vol 22, (October 2007), pp. (310-319).

Sealey J.E., Catanzaro D.F., Lavin T.N., Gahnem, F., Pitarresi T., Hu L.F., \& Laragh J.H. Specific prorenin/renin binding (ProBP). Identification and characterization of a novel membrane site. Am. J. Hypertens., vol. 9, no. 5, (May 1996), pp. (491-502).

Sealey J.E., \& Rubattu S. Prorenin and renin as separate mediators of tissue and circulating systems. Am. J. Hypertens., vol. 2, no. 5, (May 1989), pp. (358-366).

Sealey J.E., Goldstein M., Pitarresi T., Kudlak T.T., Glorioso N., Fiamengo S.A., \& Laragh J.H. Prorenin Secretion From Human Testis: No Evidence for Secretion of Active Renin or Angiotensinogen. J. Clin. Endocrinol. Metab., vol. 66, no. 5, (May 1988), pp. (974-978).

Shaw K.J., Do Y.S., Kjos S., Anderson P.W., Shinagawa T., Dubeau L., Hsueh W.A. Human decidua is a major source of renin. J. Clin. Invest., vol. 83, no. 6, (June 1989), pp. (2085-2092).

Shinagawa, T., Do., Y.S., Baxter, J.D., Carili, C., Schilling, J. \& Hseuh, W. Identification of an enzyme in human kidney that correctly processes prorenin. Proc. Natl. Acad. Sci., U.S.A., vol. 87, no. 5, (March 1990), pp. (1927-1931).

Shinagawa T., Nakayama K., Uchiyama Y., Kominami E., Doi Y., Hashiba K., Yano K., Hseu W.A., \& Murakami K. Role of cathepsin B as prorenin processing enzyme in human kidney. Hypertens. Res., vo. 18, no. 2, (June 1995), pp. (131-136).

Strausberg R.L., Feingold E.A., Grouse L.H., Derge, J.G.; Klausner, R.D.; Collins, F.S.; Wagner, L.; Shenmen, C.M.; Schuler, G.D.; Altschul, S.F.; Zeeberg, B.; Buetow, K.H.; Schaefer, C.F.; Bhat, N.K.; Hopkins, R.F.; Jordan, H.; Moore, T.; Max, S.I.; Wang, J.; Hsieh, F.; Diatchenko, L.; Marusina, K.; Farmer, A.A.; Rubin, G.M.; Hong, L.; Stapleton, M.; Soares, M.B.; Bonaldo, M.F.; Casavant, T.L.; Scheetz, T.E.; Brownstein, M.J.; Usdin, T.B.; Toshiyuki, S.; Carninci, P.; Prange, C.; Raha, S.S.; Loquellano, N.A.; Peters, G.J.; Abramson, R.D.; Mullahy, S.J.; Bosak, S.A.; McEwan, P.J.; McKernan, K.J.; Malek, J.A.; Gunaratne, P.H.; Richards, S.; Worley, K.C.; Hale, S.; Garcia, A.M.; Gay, L.J.; Hulyk, S.W.; Villalon, D.K.; Muzny, D.M.; Sodergren, E.J.; Lu, X.; Gibbs, R.A.; Fahey, J.; Helton, E.; Ketteman, M.; Madan, A.; Rodrigues, S.; Sanchez, A.; Whiting, M.; Madan, A.; Young, A.C.; Shevchenko, Y.; Bouffard, G.G.; Blakesley, R.W.; Touchman, J.W.; Green, E.D.; Dickson, M.C.; Rodriguez, A.C.; Grimwood, J.; Schmutz, J.; Myers, R.M.; Butterfield, Y.S.; Krzywinski, M.I.; Skalska, U.; Smailus, D.E.; Schnerch, A.; Schein, J.E.; Jones, S.J.; Marra, M.A. Generation and initial analysis of more than 15,000 full-length human and mouse cDNA sequences", Proc. Natl. Acad. Sci. USA, vol. 99, no. 26, (December 2002), pp. (16899-16903).

Smith A.N., Skaug J., \& Choateetal K.A. Mutations in ATP6N1B, encoding a new kidney vacuolar proton pump 116-kD subunit, cause recessive distal renal tubular acidosis with preserved hearing. Nature Genetics., vol. 26, no. 1, (September 2000), pp. (7175). 
Siragy H.M., \& Carey R.M. The subtype-2 (AT) angiotensin receptor mediates renal production of nitric oxide in conscious rats. J. Clin. Invest., vol. 100, no. 2, (1997), pp. (264-269).

Siragy H.M., \& Huang J. Renal (pro)renin receptor upregulation in diabetic rats through enhanced angiotensin $\mathrm{AT}_{1}$ receptor and NADPH oxidase activity. Exp. Physiol., vol. 93, no. 5, (May 2008), pp. (709-714).

Susic D., Zhou X., Frohlich E.D., Lippton H., \& Knight M. Cardiovascular effects of prorenin blockade in genetically hypertensive rats (SHR) on normal and high salt diet. Am. J. Physiol. Heart Circ. Physiol., vol. 295, no. 3, (September 2008), pp. (H1117-H1121).

Sun Y., Cleutjens J.P.M., Diaz-Arias A.A., \& Weber K.T. Cardiac angiotensin converting enzyme and myocardial fibrosis in the rat. Cardiovasc. Res., vol 28, no. 9, (September 1994), pp. (1423-1432).

Suzuki F., Ludwig G., Hellmann W., Paul M., Lindpaintner K., Murakami K., \& Ganten D. Renin gene expression in rat tissues: a new quantitative assay method for rat renin mRNA using synthetic cRNA. Clin. Exp. Hyper. A., vol. 10, no. 2, (1987), pp. (345359).

Suzuki F., Nakagawa T., Kakidachi H., Murakami K., Inagami T., \& Nakamura Y. The dominant role of the prosegment of prorenin in determining the rate of activation by acid or trypsin: studies with molecular chimeras. Biochem. Biophys. Res. Commun., vol. 267, no. 2, (January 2000), pp. (:577-580).

Suzuki F., Hayakawa M., Nakagawa T., Uddin M.N., Ebihara A., Iwasawa A., Ishida Y., Nakamura Y., \& Kazuo M. Human prorenin has 'gate and handle' regions for its non-proteolytic activation. J. Biol. Chem., vol. 278, no. 25, (June 2003), pp. (2221722222).

Tada, M.; Fukamizu, A.; Seo, M.S.; Takahashi, S.; Murakami, K. Renin expression in the kidney and brain is reciprocally controlled by captopril. Biochem. Biophys. Res. Commun., vol. 159, no. 3, (March 1989), pp. (1065-1071).

Tada M., Takahashi S., Miyano M., \& Miyake Y. Tissue-specific regulation of renin-binding protein gene expression in rats. The J. Biochem., vol. 112, no. 2, (August 1992), pp. (175-182).

Takahashi H., Ichihara A., Kaneshiro Y., Inomata K., Sakoda M., Takemitsu T., Nishiyama A., \& Itoh H. Regression of nephropathy developed in diabetes by (Pro)renin receptor blockade. J. Am. Soc. Nephrol., vol 18, no. 7, (July 2007), pp. (2054-2061).

Takahashi K., Hiraishi K., Hirose T., Kato I., Yamamoto H., Shoji I., Shibasaki A., Kaneko K., Satoh, F., \& Totsune K. Expression of (Pro)renin Receptor in the Human Brain and Pituitary, and Co-localisation with Arginine Vasopressin and Oxytocin in the Hypothalamus. J. Neuroendocrinol., vol. 22, no. 5, (May 2010), pp. (453-459).

Takahashi S., Ohsawa T., Miura R., \& Miyake Y. Purification and characterization of renin binding protein (RnBP) from porcine kidney. The J. Biochem., vol. 93, no. 6, (June 1983), pp. (1583-1594).

Tigerstedt R., \& Bergman P.G. Niere and Kreislauf. Scand Arc Physiol., vol. 8, no. , (1898), pp. (223-271).

Toei M., Saum R., \& Forgac M. Regulation and isoform function of the V-ATPases. Bochemistry, vol. 49, no. 23, (June 2010), pp. (4715-4723). 
van Esch J.H.M., van Veghel R, Garrelds I.M., Leijten F, Bouhuizen A. M., \& Danser A.H.J. Handle Region Peptide Counteracts the Beneficial Effects of the Renin Inhibitor Aliskiren in Spontaneously Hypertensive Rats. Hypertension, vol. 57, no. 4, (February 2011), pp. (852-858).

Van Gilst W.H., de Graeff P.A., Kingma J.H., Wesseling H., \& de Langen C.D.J. Captopril reduces purine loss and reperfusion arrhythmias in the rat heart after coronary artery ligation. Eur. J. Pharmacol., vol. 100, no. 1, (April 1984), pp. 113-117.

van Kesteren C.A., Saris J.J., Dekkers D.H., Lamers J.M., Saxena P.R., Schalekamp M.A., Danser A.H.J. Cultured neonatal rat cardiac myocytes and fibroblasts do not synthesize renin or angiotensinogen: evidence for stretch-induced cardiomyocyte hypertrophy independent of angiotensin II. Cardiovasc. Res., vol. 43, no. 1, (July 1999), pp. 148-156.

van Kesteren C.A.M., Danser A.H.J., Derkx F.H., Dekkers D.H., Lamers J.M., Saxena P.M., \& Schalekamp M.A. Mannose 6-phosphate receptor-mediated internalization and activation of prorenin by cardiac cells. Hypertension, vol. 30, no. 6, (December 1997), pp. (1389-1396).

Wang P.H., Do Y.S., Macaulay L., Shinagawa T., Anderson P.W., Baxter J.D., \& Hseuh W.A. (1991) Identification of renal cathepsin B as a human prorenin-processing enzyme. J. Biol. Chem., vol. 266, no. 19, (July 1991), pp. (12633-12638).

Webb, D.J., Manhem, P.J., Ball, S.G., Inglis, G., Leckie, B.J., Lever, A.F., Morton, J.J., Robertson, J.I., Murray, G.D., Ménard, J., et al. A study of the renin inhibitor H142 in man. J. Hypertens., vol. 3, no. 6, (December 1985), pp. (653-658).

Wilkinson-Berka, J.L., Heine R., Tan G., Cooper M.E., Hatzopoulos K.M., Fletcher E.L., Binger K.J., Campbell D.J., \& Miller A.G. RILLKKMPSV influences the vasculature, neurons and glia, and (pro)renin receptor expression in the retina. Hypertension, vol. 55, no. 5, (June 2010), pp. (1454-1460).

Wilson C.M., Cherry M., Taylor B.A., \& Wilson J.D. Genetic and endocrine control of renin activity in the submaxillary gland of the mouse. Biochem. Genet., vol. 19, no. (5-6), (June 1981), pp. (509-523)

Wolny A., Clozel J.P., Rein J., Mory P., Vogt P., Turino M., Kiowski W. F., Ischli W. Functional and biochemical analysis of angiotensin II-forming pathways in the human heart. Circ.Res., vol. 80, no. 2, (February 1997), pp. (219-227).

Wood J.M., Gulati N., Forgiarini P., Fuhrer W. \& Hofbauer, K.G. Effects of a specific and long-acting renin inhibitor in the marmoset. Hypertension, vol. 7, no. 5, (October 1985), pp. (797-803).

Wood J.M., Criscione L., de Gasparo M., Bühlmayer P., Rüeger H., Stanton J.L., Jupp R.A. \& Kay J. CGP 38 560: orally active, low-molecular-weight renin inhibitor with high potency and specificity. J. Cardiovasc. Pharmacol., vol. 14, no. 2, (August 1989), pp. (221-226).

Wood J.M., Cumin F. \& Maibaum J. Pharmacology of renin inhibitors and their application to the treatment of hypertension. Pharmacol. Ther., vol. 61, no. 3, (1994) pp. (325344).

Wood J.M., Maibaum J., Rahuel J., Grütter MG., Cohen NC., Rasetti V., Rüger H., Göschke R., Stutz S., Fuhrer W., Schilling W., Rigollier P., Yamaguchi Y., Cumin F., Baum HP., Schnell CR., Herold P., Mah R., Jensen C., O'Brien E., Stanton A., \& Bedigian 
MP. Structure-based design of aliskiren, a novel orally effective renin inhibitor. Biochem. Biophys. Res .Commun., vol. 308, no. 4, (September 2003), pp. (698-705).

Yokosawa H., Inagami T., \& Haas E. Purification of human renin. Biochem. Biophys. Res. Commun., vol. 83, no. 1, (July 1978), pp. (306-312).

Yokosawa H., Holladay L.A., Inagami T., Haas E. \& Murakami K. Human renal renin: complete purification and characterization. J. Biol. Chem., vol. 255, no. 8, (April 1980), pp. (3498-3502).

Yoshikawa A., Kusano Y.K., Kishi F., Kishi F,; Susumu T., Iida S., Ishiura S., Nishimura S., Shichiri M., \& Senbonmatsu T. The (pro)renin receptor is cleaved by ADAM19 in the Golgi leading to its secretion into extracellular space. Hypertens. Res., vol. 34, no. 5, (May 2011), pp. (599-605).

Yusuf S., on behalf of the SOLVD investigators. Effect of enalapril on survival in patients with reduced left ventricular ejection fractions and congestive heart failure. N. Engl. J. Med., vol. 325, no. 5, (August 1991), pp. (293-302).

Zhang X., Dostal D.E., Reiss K., et al. Identification and activation of autocrine reninangiotensin system in adult ventricular myocytes. Am. J. Physiol., vol. 269, no. 5, (November 1995), pp. (H1791-H1802).

Zhang J., Noble N.A., Border W.A., Owens R.T., \& Huang Y. Receptor-dependent prorenin activation and induction of PAI-1 expression in vascular smooth muscle cells. Am. J. Physiol. Endocrinol. Metab., vol. 295, no. 4, (October 2008), pp. (E810-E819). 


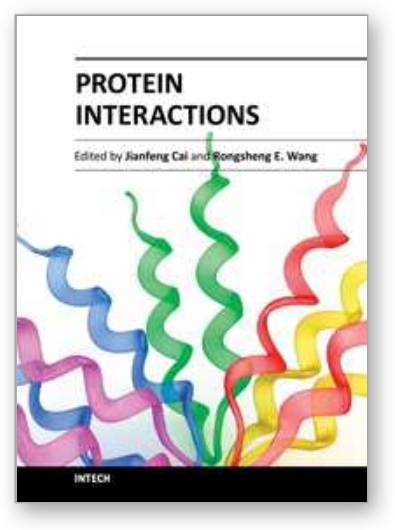

\author{
Protein Interactions \\ Edited by Dr. Jianfeng Cai
}

ISBN 978-953-51-0244-1

Hard cover, 464 pages

Publisher InTech

Published online 16, March, 2012

Published in print edition March, 2012

Protein interactions, which include interactions between proteins and other biomolecules, are essential to all aspects of biological processes, such as cell growth, differentiation, and apoptosis. Therefore, investigation and modulation of protein interactions are of significance as it not only reveals the mechanism governing cellular activity, but also leads to potential agents for the treatment of various diseases. The objective of this book is to highlight some of the latest approaches in the study of protein interactions, including modulation of protein interactions, development of analytical techniques, etc. Collectively they demonstrate the importance and the possibility for the further investigation and modulation of protein interactions as technology is evolving.

\title{
How to reference
}

In order to correctly reference this scholarly work, feel free to copy and paste the following:

A.H.M. Nurun Nabi and Fumiaki Suzuki (2012). Biochemical, Structural and Pathophysiological Aspects of Prorenin and (Pro)renin Receptor, Protein Interactions, Dr. Jianfeng Cai (Ed.), ISBN: 978-953-51-0244-1, InTech, Available from: http://www.intechopen.com/books/protein-interactions/biochemical-structural-andpathophysiological-aspects-of-prorenin-and-pro-renin-receptor

\section{INTECH}

open science | open minds

\section{InTech Europe}

University Campus STeP Ri Slavka Krautzeka 83/A 51000 Rijeka, Croatia

Phone: +385 (51) 770447

Fax: +385 (51) 686166 www.intechopen.com

\section{InTech China}

Unit 405, Office Block, Hotel Equatorial Shanghai No.65, Yan An Road (West), Shanghai, 200040, China 中国上海市延安西路65号上海国际贵都大饭店办公楼405单元 Phone: +86-21-62489820

Fax: +86-21-62489821 
(C) 2012 The Author(s). Licensee IntechOpen. This is an open access article distributed under the terms of the Creative Commons Attribution 3.0 License, which permits unrestricted use, distribution, and reproduction in any medium, provided the original work is properly cited. 